\title{
Chapter 8 \\ Insect Pests Affecting Potatoes in Tropical, Subtropical, and Temperate Regions
}

\author{
Jürgen Kroschel, Norma Mujica, Joshua Okonya, and Andrei Alyokhin
}

\begin{abstract}
Ensuring the sustainable production of potato is an important challenge facing agriculture globally. Insect pests are major biotic constraints affecting potato yields and tuber quality. The high pesticide uses to control them is of high human and environmental health concern, and it is expected that this will be further exacerbated through impacts of climate change. The chapter provides an overview of the geographical distribution of potato insect pests and their importance in tropical, subtropical, and temperate potato production regions. Climate change will potentially contribute to expand their geographical range of distribution, and increasing populations will lead to greater crop and post-harvest losses. Good progress has been made in applying insect pest modeling in pest risk analysis of potato pests to inform and create better awareness of future pest risks under climate change. Potato pests include some of the species which have evolved resistance to a wide variety of chemicals; and potato growers have already experienced the situation that available chemicals failed to control their targets. This chapter emphasizes the development, use, and adaptation of Integrated Pest Management (IPM) across all potato-growing regions of the world. Ultimately, this will lead to sustainable and more resilient potato production systems not overly dependent on pesticides. IPM requires a good knowledge and understanding of individual potato production systems; identifying pest species, knowing their biology and symptoms of infestation is essential for making educated decisions on their integrated management. To address this need,
\end{abstract}

\footnotetext{
J. Kroschel $(\bowtie)$

Independent Consultant for International Agricultural Research \& Development,

Filderstadt, Germany

e-mail: jurgen.kroschelconsult@outlook.com

N. Mujica

Independent Consultant, Lima, Peru

J. Okonya

International Potato Center, Kampala, Uganda

e-mail: J.Okonya@cgiar.org
}

\author{
A. Alyokhin \\ University of Maine, Orono, ME, USA \\ e-mail: alyokhin@maine.edu
}


the chapter provides detailed information for a total of 49 insect pests of potato and the status quo of their management around the world.

\subsection{Introduction}

The potato (Solanum tuberosum L.) is native to the Andean highlands of South America. Today, potato is produced in more than 149 countries in temperate, subtropical, and tropical agroecologies, demonstrating the versatility and adaptability of this crop to a wide range of environmental conditions. Potato provides humans with an abundant and relatively inexpensive source of high-quality nutrients. Historically, their incorporation into everyday diets commonly coincided with periods of rapid population growth in a variety of nations (Zuckerman 1999). Presently, potatoes continue playing a very important role in feeding the human population. The last 30 years were characterized by an explosive growth in their popularity in Asia and Africa, which were previously reliant on other staple crops. Therefore, ensuring sustainability of potato production is currently an important challenge facing agricultural professionals worldwide (Vincent et al. 2013). Insect pests are major biotic factors affecting potato yield and tuber quality. Globally, losses are estimated on average at 16\% (Oerke et al. 1994). Locally, if not routinely controlled, reductions in tuber yield and quality can be between 30 and $70 \%$ for various pests (Mujica and Kroschel 2013; Kroschel and Schaub 2013). The high pesticide use in potato is of high human and environmental health concern, which needs to be addressed by developing and more widely implementing Integrated Pest Management (IPM) approaches.

\subsection{Potato Insect Pests' Geographical Distribution and Invasiveness}

Due its global geographical distribution, potato is affected by a wide range of insect pests. In this book chapter we listed and described a total of 49 species: nine major species occurring in tropical and subtropical regions; two major species affecting potato in temperate regions; six major and 32 minor species of temperate, subtropical, and tropical regions. Farmers in tropical and subtropical countries must contend with a higher number of pest species, and with some exceptions, a minimum of 2-4 pests often reach pest status requiring the application of control methods (Kroschel et al. 2012). Many pests have evolved in the center of potato origin, and farmers in the Andean region are confronted by a higher number of pests than farmers in Africa or Asia. Some species such as the potato tuber moth, Phthorimaea operculella (Zeller), and the leafminer fly, Liriomyza huidobrensis (Blanchard) have become invasive and occur today as serious pests in many tropical and subtropical regions. 
In contrast, the strong adaptation of Andean potato weevils, Premnotrypes spp., to the climate of the Andean region and its monophagous feeding habitat on potato and its wild relatives have restricted its distribution. There are, however, still several other pests which could also gain global proportions. Just very recently in 2006, the tomato leaf miner, Tuta absoluta Meyrick, although a more minor pest in potato, was unintentionally introduced to Spain, from where it continued its devastating journey across Africa and into Asia where it reached India within less than 10 years. As farmers had not been prepared and no control measures had been in place, the pest caused large production losses in tomato (Lycopersicon esculentum Mill.); under certain conditions also potato was more heavily infested as known from South America. The bud midge, Prodiplosis longifilia Gagne, currently with a restricted distribution in Florida and Virginia, and South America (Colombia, Peru, and Ecuador) could become an invasive species supported by its very polyphagous feeding habit. The Colorado potato beetle, Leptinotarsa decemlineata (Say), native to Mexico, has spread across most of the United States, and was introduced into France in the 1920s from where it spread further reaching also parts of China (CABI 2017a).

\subsection{Impacts of Climate Change on Potato Insect Pests}

Climate, especially temperature, has a strong and direct influence on the development and growth of insect pest populations. Herbivorous insects - as all other arthropods - are exothermic organisms that cannot internally regulate their own temperature. Their development depends on the temperature to which they are exposed in the environment. A rise in temperature due to climate change may both increase or decrease pest development rates and related crop losses. Hence, an increase in temperature can potentially affect range expansion and outbreaks of many insect pests including pests of potato.

Innovative modeling approaches such as process-based climatic response phenology models (Orlandini et al. 2017; Mujica et al. 2017; Sporleder et al. 2004, 2017) have been used to assess the effect of temperature increase under projected changes in global temperature for the year 2050 (Kroschel et al. 2016a) for a wide range of potato pests: P. operculella (Kroschel et al. 2013, 2016b); L. huidobrensis (Mujica et al. 2016); Guatemalan potato tuber moth, Tecia solanivora (Povolny) (Schaub et al. 2016); Andean potato tuber moth, Symmetrischema tangolias (Gyen) (Sporleder et al. 2016); the White flies, Bemisia tabaci (Gennadius) and Trialeurodes vaporariorum (Westwood) (Gamarra et al. 2016a, b).

These predictions have clearly demonstrated that insect pests of potato will respond to climate change by expanding their geographical range of distribution and increasing population densities will lead to greater crop and post-harvest losses. There are, however, distinct differences among the different pest species. The damage potential of $P$. operculella for example will potentially progressively increase in all regions where the pest already prevails today, with a range expansion into 
temperate and tropical mountainous regions (Kroschel et al. 2013, 2016b). In comparison, $L$. huidobrensis is much less adapted to warmer climates and climate change will differently affect this species. The global predictions clearly indicate a slight to moderate decrease in the establishment potential of the pest in most of the tropical and subtropical potato production areas, but still with high pest risks. Further, a range expansion into temperate regions of Asia, North and South America, and Europe, as well as into subtropical and tropical mountainous regions is expected, with a moderate increase of its establishment and damage potential (Mujica et al. 2016). A further range expansion into tropical mountainous regions such as the Andes has been also predicted for T. solanivora and S. tangolias (Quiroz et al. 2018).

Potato production systems of tropical countries are highly susceptible to pest infestations due to often year-round favorable climatic conditions for pest population growth and host plant availability. Even smaller changes in temperature predicted for tropical regions compared to temperate regions will have stronger consequences on pest development due to already higher existing metabolism rates of organisms such as insects (Dillon et al. 2010). This does affect not only the general life cycle of an insect pest but also all other biological processes, including feeding rates, plant growth, and activity of biotic antagonist. Lessons have been learnt from the El Niño phenomena to better understand possible climate change effects on pest abundance and severity in tropical production areas. During the 1997 El Niño phenomena in Peru, the mean temperature on the Peruvian coast increased by about $5{ }^{\circ} \mathrm{C}$ above the annual average. While infestation of potato by L. huidobrensis decreased, infestations by all other pests increased in agricultural and horticultural crops. The farmers' only adaptive strategy to cope was to apply high doses of pesticides every 2-3 days (Cisneros and Mujica 1999a).

\subsection{Insect Pest Control with Insecticides in Potato}

Potato foliage contains a considerable amount of glycoalkaloids, which provide at least some protection from herbivory. Nevertheless, they are attacked by a robust complex of phytophagous insects, some of which can destroy the potato crop in the absence of adequate control measures. Just as with most other cultivated plants, management of insect pests of potato is achieved predominantly through application of pesticides. By some estimates, potatoes are the most chemically dependent crop in the world (Vincent et al. 2013). Insect pests are not the only factor responsible for this notoriety, as large amounts of fungicides are used to combat diseases caused by fungi and oomycetes. Still, insecticides remain to be a foundation of insect pest management in most potato fields around the world, and their use can be rather heavy at times.

Although insecticides have been largely successful in keeping potato production going, there are serious and well-known concerns about long-term sustainability of this approach. Nontarget effects of insecticides on a variety of organisms, including 
humans and beneficial insects, gained considerable notoriety since 1960s. The use of highly hazardous pesticides in potato in countries such as Ecuador and Peru has caused serious health risks to farmers (Orozco et al. 2009). Worldwide decline in beneficial pollinators documented in the early 2000s provided additional fuel to the fire of public apprehension of using toxic chemicals in agriculture. Furthermore, as discussed in the following section, more and more insecticides have lost their efficiency due to resistance development in insect populations (Alyokhin et al. 2013, 2015).

As more and more insecticides are becoming phased out due to environmental concerns or become ineffective due to resistance development in targeted insect populations, the number of options available to potato growers dwindles. Developing replacement insecticides is an increasingly difficult and expensive task, and it is highly questionable that a plethora of new active ingredients will regularly appear on the market in perpetuity (Alyokhin et al. 2015). Therefore, good stewardship of existing chemicals and, whenever possible, their replacement with nonchemical control alternatives become an increasingly important business strategy for the pesticide industry and potato farmers. Therefore, this chapter puts a considerable emphasis on describing various nonchemical management options for insect pests.

In the modern age of industrialized agriculture, a farmer field is often considered to be a type of a production facility. Although there is a certain element of truth to such an approach, it is important to remember that it is still comprised of living organisms that are interacting with each other and with their environment. In other words, it is an ecosystem, with the same basic characteristics as all other ecosystems on Earth. This includes evolutionary processes leading to adaptation to a particular set of environmental conditions through survival and reproduction of specific genotypes. In many cases, such an adaptation means developing an ability to survive exposure to insecticides, a phenomenon known as insecticide resistance (Alyokhin et al. 2015).

Potato pests include some of the species that are most prone to evolving resistance to a wide variety of chemicals. The Arthropod Pesticide Resistance Database (2018) lists 469 cases of green peach aphid (Myzus persicae (Sulzer)) resistance to a total of 80 active ingredients; 300 cases of Colorado potato beetle (Leptinotarsa decemlineata (Say)) resistance to a total of 56 active ingredients; 111 cases of greenhouse whitefly (T. vaporariorum) resistance to 27 active ingredients; and 501 cases of two-spotted spider mite (Tetranychus urticae C. L. Koch) resistance to rather impressive 95 active ingredients. The extent of resistance is likely to be underestimated because not every case of its development is entered into the database. It is possible that the ability to deal with toxic glycoalkoloids contained in potato foliage serves as a preadaptation to resisting chemical toxins made by humans (Alyokhin and Chen 2017). Not every population of a given pest species is resistant to all compounds that have been recorded to fail against that species. However, these statistics vividly illustrate the seriousness of the problem. On several occasions, potato growers already experienced the situation when virtually all commercially available chemicals failed to control their targets (Alyokhin et al. 2013). It is very 
likely that such a situation will arise again in the foreseeable future. Therefore, we need to be proactive to prevent this from happening.

Insecticide resistance is usually associated with several traits that may be taken advantage of when devising resistance management plans. Due to the pleiotropic effects of resistant alleles, in the absence of insecticides resistant insects often have lower reproductive output and/or suffer higher mortality. As a result, they are being outcompeted by susceptible insects. Also, in many cases resistance is inherited as an incompletely dominant or an incompletely recessive trait. Therefore, insects that are heterozygous at the resistant locus can be successfully controlled with sufficiently high dose of insecticide. So, resistance management techniques are generally directed towards preventing the situation when only highly resistant homozygotes survive in a population (Alyokhin et al. 2013, 2015). In practical terms, this can be achieved by doing the following:

- Monitoring insecticide efficacy. Larger than usual number of surviving pests may indicate that their population is becoming resistant.

- Avoiding applications of the same or related products repeatedly throughout a growing season. Instead, application schedule should consist of a sequence of insecticides with different modes of action. Information on a product's mode of action is available from its manufacturer.

- Applying insecticides at rates that are not lower than a recommended minimum. Otherwise, heterozygotes will survive and breed with each other. Following Mendelian laws of inheritance, some of their offspring will become homozygously resistant and capable of surviving even the recommended insecticide rates.

- Applying insecticides only when pest populations are sufficiently high to cause economically important damage. Therefore, the use of control thresholds developed for different potato pests is highly recommended. Trying to kill every single insect will, by definition, result in the survival of only highly resistant genotypes.

- Whenever possible, leaving parts of the field untreated to allow susceptible pests to survive and interbreed with resistant pests. Because resistance is almost never completely dominant, resulting heterozygotes will be killed by insecticides.

- The use of insecticide applications should be not the first but the ultimate control option in an IPM approach after all other management options could not prevent to keep a specific pest population under the economic threshold.

\subsection{Integrated Pest Management in Potato}

Integrated Pest Management (IPM) is defined as an "ecosystem approach to crop production and protection that combines different management strategies and practices to grow healthy crops and minimize the use of pesticides." It means "a careful consideration of all available pest control techniques and subsequent integration of 
appropriate measures that discourage the development of pest populations and keep pesticides and other interventions to levels that are economically justified and reduce or minimize risks to human health and the environment. IPM emphasizes the growth of a healthy crop with the least possible disruption to agro-ecosystems and encourages natural pest control mechanisms" (FAO 2018). It has been also defined as "a decision support system for the selection and use of pest control tactics, singly or harmoniously coordinated into a management strategy, based on cost/benefit analyses that consider the interests of and impacts on producers, society, and the environment" (Kogan 1998).

Although IPM has been widely promoted by researchers, policymakers, and agricultural practitioners, it is still very far from being universally adopted, but there have been large shifts towards bringing it into the mainstream of agricultural production. Since 2014, for example, a European Union (EU) Directive has obliged all professional plant growers within the Union to apply the general principles of IPM (European Parliament and the Council of the European Union 2009). To make IPM, however, successful, integrating several methods to combat pests requires interdisciplinary research and effective nonchemical control methods for all pests in a specific crop agroecology to fully avoid or minimize the pesticide use. But many research programs working on IPM still focus on single plant protection methods and not on a systematic study of the compatibility and optimization of simultaneously implemented pest management elements (Stenberg 2017). The International Potato Center (CIP) has developed a holistic working framework for potato pest management research and development and its application by farmers. This approach led, for example, to the development of IPM for different potato agroecologies in Peru under smallholder production considering ecological, economic, and environmental benefits (Mujica and Kroschel 2018; Kroschel et al. 2012). Further, Horn and Page (2008) reported from a successful potato IPM program for large-scale potato growers in Australia.

Individual potato IPM programs vary greatly depending on the specific agroecology and the socioeconomic conditions for which it is developed or adapted. However, they all share several important components, which distinguish them from the so-called conventional approaches that largely rely on calendar-based sprayings of pesticides.

- Application of best cultural practices, which includes the use of healthy seed, suitable crop rotations, and intercropping systems among others which also support natural biological control.

- Correct and timely pest identification and regular monitoring of population development. This applies the use of monitoring tools such as pheromone- or physical-based trapping methods (e.g., yellow sticky traps). Educated pest management takes advantage of specific aspects of pest biology that can be used to diminish its populations in one way or another. It should also be preventative, initiated before the occurrence of economic losses.

- Application of economic thresholds. Attempts on complete pest elimination are costly, often futile, and generally counterproductive. A control action should be 
taken only when the cost of damage due to injury by a pest exceeds the cost of the control action. Control thresholds have been developed for several potato pests, but they need to be verified and adjusted for the conditions of a specific location and potato variety.

- Using diverse control tactics in a complementary or, whenever possible, synergistic ways. Pesticides are the ultimate option integrated with cultural, biological, regulatory, and other controls to result in a unified multi-pronged attack against pest populations.

- Evaluating results. This component is often overlooked, but very important. Efficiency of IPM control programs should be continuously monitored to make necessary adjustments when needed considering economic, ecological, and environmental assessments.

Among other benefits, IPM is likely to dramatically slow down evolution of insecticide resistance. Simultaneous adaptations to diverse and unrelated management techniques will require statistically unlikely genetic changes in pest populations (Alyokhin et al. 2015). As a result, integrating different techniques is likely to reduce our reliance on the "pesticide treadmill" of constantly replacing failed chemicals. With all its advantages, IPM should be made available to farmers across all potato-growing areas of the world. Practicing this approach requires, however, a good understanding of individual production systems down to a single-field level and knowing their specific components. Identifying pest species and knowing their biology is essential for making educated decisions on their management. To address this need, the following subchapters provide an overview of major and minor insect pests of potato and their management around the world.

\subsection{Major Pests in Tropical and Subtropical Regions}

\subsubsection{Potato Tuber Moths}

\section{Phthorimaea operculella (Zeller, 1873), Symmetrischema tangolias (Gyen, 1913), Tecia solanivora (Povolny, 1973) (Lepidoptera: Gelechiidae)}

Distribution The potato tuber moth (PTM), Phthorimaea operculella, originated in the tropical mountainous regions of South America. Today it has a worldwide distribution and is considered the most damaging potato pest in the developing world (Fig. 8.1). It is present in almost all tropical and subtropical regions of the world, in North, Central, and South America, Africa, Asia, Australia, and Europe. The Andean potato tuber moth (APTM), Symmetrischema tangolias, is native to South America (Peru and Bolivia) but has in the last decades spread to other regions of the world (Fig. 8.2). Records include North America, Australia, New Zealand, and more recently Indonesia. Although this species is known as a pest of potato and tomato in South America and the Australian region, it does not attack any of these 

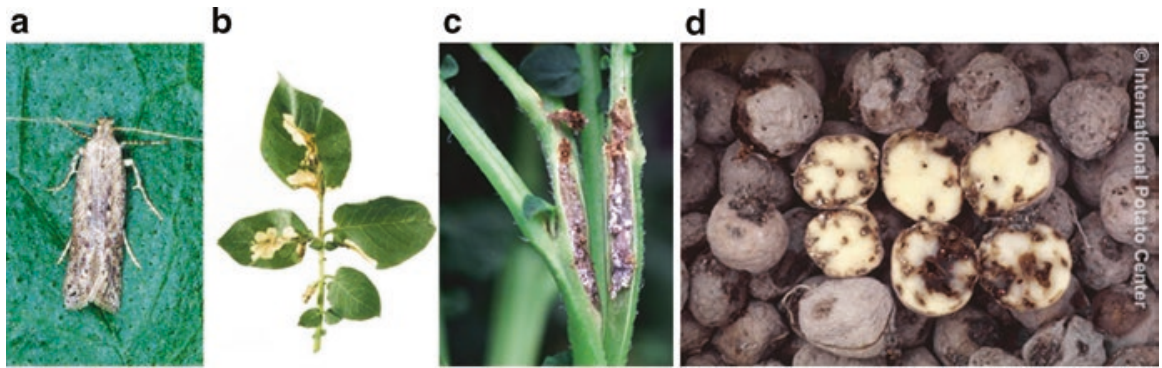

Fig. 8.1 Adult female of Phthorimaea operculella (a) and symptoms of larvae infestation on leaves, stems, and tubers $(\mathbf{b}, \mathbf{c}, \mathbf{d})$. (Photo credits: CIP)

a

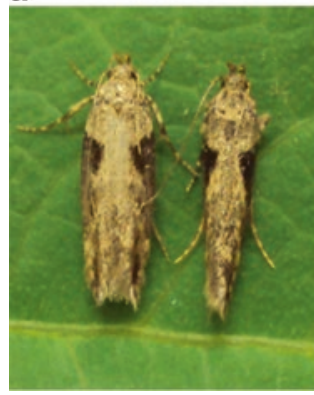

b

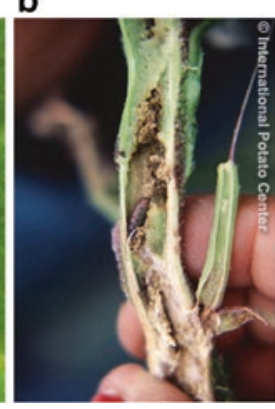

C

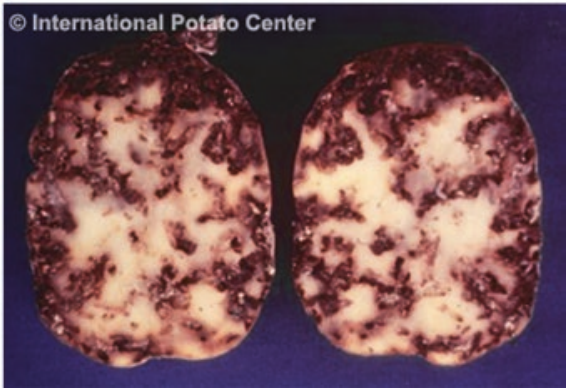

Fig. 8.2 Adult male and female of Symmetrischema tangolias (a), and symptoms of larvae infestation on stems and tubers $(\mathbf{b}, \mathbf{c})$. (Photo credits: CIP)

two crops in North America but instead feeds on black nightshade (Solanum americanum Mill.). The Guatemalan potato tuber moth (GPTM), Tecia solanivora, probably originated from Guatemala and is endemic throughout Central America (Fig. 8.3). In 1983, the pest was unintentionally introduced into Venezuela and then invaded Colombia and Ecuador. In 2000, T. solanivora was introduced in the Canary Islands (Tenerife). Since then the pest has been considered as a major threat to potato throughout southern Europe and was listed as a quarantine pest by the European and Mediterranean Plant Protection Organization (EPPO 2005a; Kroschel et al. 2016a, b; Kroschel and Schaub 2013). In 2014, it was finally recorded in mainland Spain where efforts are going on to eradicate the pest (Jeger et al. 2018).

Host range $P$. operculella is an oligophagous pest (i.e., an insect feeding on a restricted range of food plants) of vegetable crops that belong mainly to the family Solanaceae: potato (Solanum tuberosum L.), tomato (Lycopersicon esculentum Mill.), and tobacco (Nicotana tabacum L.). Also, wild species of the Solanaceae family, including important weeds, e.g., black night shade (Solanum nigrum L.) are hosts. In total, the host range comprises 60 species. Further, crops of the family Chenopodiaceae are attacked including eggplant (Solanum melongena L.), bell 

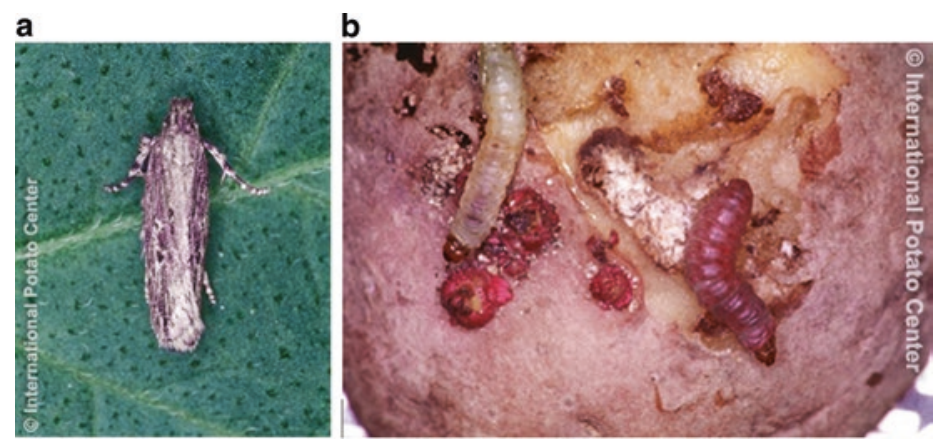

Fig. 8.3 Adult male of Tecia solanivora (a), and symptoms of larvae infestation on tubers (b). (Photo credits: CIP)

pepper (Capsium annuum L.), Cape gooseberry (Physalis peruviana L.), aubergine (S. melongena L.), and sugar beet (Beta vulgaris L.). S. tangolias has a more restricted host range comprising of potato, tomato, sweet cucumber (Solanum muricatum Aiton), poroporo (Solanum aviculare G. Forst), kangaroo apple (Solanum laciniatum Aiton), black nightshade, and bell pepper. T. solanivora is monopahagous attacking only potato.

Symptoms of infestation $P$. operculella attacks potato by mining the leaves and stems and by feeding on the tuber. Mines are the typical symptoms of leaf damage caused by the larvae eating the mesophyll without damaging the upper and lower epidermis. When the foliage dies, the larvae enter the soil through cracks where they may eventually find and feed upon tubers. Larvae enter potato tubers via the eyes and continue to bore or tunnel through the tuber just below the skin. Larval excreta are pushed out through the holes, which can be observed immediately after larvae start their mining activity. Larvae of APTM enter the potato stem making a small hole in the plant axils (between stem and lateral petioles). From this hole, galleries made by the larvae run downward within the stem. Excreta are pushed out through the initial hole made by the larva. When stems are severely damaged, the upper part of the stem wilts or the whole plant collapses. Young plants can suffer tip death from boring larvae. Eggs may be found in slits on the stem of a food plant. In tubers, larvae enter through potato eyes. Initially, the small hole can hardly be seen by the naked eye. As in stems, larval excreta are then pushed out through the hole, which becomes apparent after several days of mining activity. Inside the tuber, the larva tunnels just under the surface at first, but later penetrates more deeply. GPTM larvae feed exclusively on tubers during potato cultivation and during storage. Damage is caused by larvae that bore galleries into the tubers. After the larvae have left tubers, the exit hole is clearly visible. In potato fields, $T$. solanivora attack occurs from tuberization until harvest (Kroschel and Schaub 2013; Niño 2004). Tubers infested by either of the three species develop a bitter taste and are unsuitable for human or livestock consumption (Keller 2003; Kroschel and Schaub 2013). 


\section{Impacts on production losses}

$P$. operculella. Under heavy field infestation, potato foliage can be destroyed, which can result in substantial yield loss of up to $70 \%$. High infestations early in the season can directly affect tuber yield. Strong correlation exists between leaf and consequent tuber infestation, which suggests that reducing $P$. operculella population density during the growing period is key to reducing potato tuber infestation at harvest. Hence, the most devastating yield losses are largely a result of earlier tuber infestation in the field, generally where moths have laid eggs through soil cracks on the developing tubers, or when harvest is delayed. P. operculella also damages harvested potato tubers in storage. The damage to potatoes in rustic stores can be total within a few months if the tubers are left untreated. Infested tubers are unsuitable not only for human consumption but also for use as seed. Infested tubers produce fewer yields and initiate a fast development of a new field $P$. operculella population (Kroschel and Schaub 2013; Kroschel et al. 2012; Keller 2003; Kroschel 1994, 1995).

S. tangolias. This species has become an economically important pest in potato fields and in storage in mid-elevation regions of the Andes (Peru, Bolivia, and Ecuador); its status in Colombia is not well confirmed. In the Andes, losses in the field may reach up to $30 \%$, but most economically significant damage occurs when infested tubers are transferred to potato stores where reinfestation takes place. Without adequate management, farmers can completely lose their house-stored potatoes within 3-4 months of storage. In Australia and New Zealand, where the pest was accidentally introduced from South America, it is more recognized as a local pest of tomato, poroporo, sweet cucumber and other Solanaceae crops, and is commonly referred to as "tomato stem borer." However, at national level it is considered a minor pest and its economic impact on these crops is not well reported in the literature (Kroschel and Schaub 2013; Keller 2003).

T. solanivora. Complete losses of harvested tubers have been observed occasionally after the invasion of the pest into new areas when farmers were not yet familiar with pest control. Generally, tuber damage rates at harvest vary between 2 and $15 \%$ in the Andean region. When infested potato tubers are stored without application of control methods $T$. solanivora can destroy, depending on the storage period and temperature, of whole potato stock (Kroschel and Schaub 2013; Niño 2004).

\section{Methods of prevention and control}

Control of the potato tuber moths must take place both in the field and in storage. Implementation of integrated pest management is recommended to reduce the pest problem in field and stores. T. solanivora is the most difficult potato moth to control as the larvae feed only inside potato tubers where they are hard to reach (Kroschel and Schaub 2013; Kroschel et al. 2012; Keller 2003; Pollet et al. 2003; Kroschel 1995).

Monitoring with pheromone traps. For all three potato tuber moth species sexual pheromones have been identified and synthesized. They are used for monitoring the flight activity of adult male populations to detect early the presence of the different moths in the field and store to take adequate control measures. 
Cultural practices. Some common practices for potato tuber moths are the use of pest-free seed tubers, deep planting, regular irrigation to avoid soil cracking, high hilling to protect tubers, timely harvest, not leaving the tubers after harvest exposed in the field for a long time (especially throughout the night), i.e., harvest and store immediately, and removal of leftover tubers to reduce the overwintering field population. Also, early maturing varieties can contribute to reduced risk of infestation.

Biological control. Classical biological control can be an effective strategy in all those regions in which the pests has been unintentionally introduced to keep the pest population below economic threshold; for this approach, the species Copidosoma koehleri (Blanchard), Apanteles subandinus (Blanchard), and Orgilus lepidus (Muesebeck) have been widely and successfully used (Canedo et al. 2016a, b, c; Kroschel and Schaub 2013).

Biopesticides. Microbial biopesticides for $P$. operculella field control have been tested based on Bacillus thuringiensis subsp. kurstaki (Btk) and P. operculellaspecific granulovirus (PhopGV, Baculoviridae). Btk was effective but required repeated applications because it is quickly degraded by UV light. Likewise, Phop GV has shown mixed results. To protect $P h o p$ GV against UV inactivation a variety of adjuvants (e.g., dyes, optical brighteners) have been tested but simple preparations of PhopGV-infected larvae macerated in water were superior. Applications of PhopGV doses sufficient to cause $>95 \%$ mortality are considered not being economical, and low dose treatments are proposed for a relatively inexpensive partial suppression of the field population (Lacey and Kroschel 2009; Sporleder and Kroschel 2008; Kroschel and Sporleder 2006; Sporleder 2003; Kroschel et al. 1996).

Attract-and-kill. This approach has been developed to control of $P$. opercullela and S. tangolias under field and storage conditions. It consists of a co-formulation of the insect pest-specific sexual pheromone, which "attracts" males, and a contact insecticide at very low concentration which "kills" males getting in contact with the product. The oil formulation is applied at a droplet size of $100 \mu \mathrm{L}$ using a special handheld applicator; it is applied at 2500 droplets/ha. It effectively reduces the male population and the number of offspring, hence controlling larvae damage in the crop. It provides pest-specific control, and is harmless to natural enemies, humans, and the environment (Kroschel and Zegarra 2010, 2013). In Peru, the two products AdiosMacho- $P o^{\circledR}$ and AdiosMacho-St ${ }^{\circledR}$ have been registered to be commercialized in Peru and the Andean region.

Chemical control. Broad-spectrum insecticides have been commonly used to suppress potato tuber moth population and economic damage, but which has been associated with many negative effects causing resistance of the pests to various active ingredients and affecting farmers and the environment.

Integrated Pest Management. Effective IPM practices for potato tuber moths have been developed, which can be applied successfully if potato tuber moths are the only economically important pests in an agroecosystem (e.g., Republic of Yemen, Kroschel 1995). However, potato is often affected by several pest species which requires a system approach to manage all economically important potato 
pests (Kroschel et al. 2012). This means effective IPM practices are required for all pests to fully eliminate or minimize the use of insecticides.

\section{Storage management}

Potato tuber moth infestation occurs frequently in rustic farmer-managed potato stores in developing countries, especially if temperature is suitable for rapid population build up and the storage lasts for several months. Storage facilities should be cleaned thoroughly before potato tubers are stored. Fine netting at windows should protect adult moths from entering storage facilities. Only healthy tubers should be selected for storage. Infested potato tubers need to be destroyed. However, initial infestations cannot be easily observed and are the main reasons why potato tuber moths enter storage facilities and infest potato. Sex-pheromone-baited water traps or funnel traps (Delta) can be used for monitoring the moth presence but in known region of potato tuber moths' occurrences, potatoes should be treated before storage.

Biopesticides. Biopesticides based on Btk and PhopGV are used in potato tuber moth storage control. The microbials are formulated in inert materials (e.g., talcum) and dusted over potatoes before storage. Since PhopGV is only effective in $P$. operculella and $T$. solanivora, in regions where all three species occur simultaneously, the use of Btk has the advantage to control all three species. Further, Btk is mostly available as a commercial biopesticide while PhopGV has to be multiplied in potato tuber moth larvae. The product Matapol, e.g., is a co-formulation between Btk and PhopGV, commercialized in Bolivia. It has also been shown that inert materials (e.g., calcium carbonate, kaolin, talcum, silicium rich sand) can be used effectively without the addition of active biologicals (Btk, or PhopGV) as they control first instar larvae through desiccation (Kroschel and Koch 1996; Mamani et al. 2011; Sporleder and Lacey 2013; Schaub and Kroschel 2017).

Attract-and-kill. Attract-and-kill formulations (see above) can be applied at a density of one drop $(100 \mu \mathrm{L}) / \mathrm{qm}$ of storage area to reduce the male population and hence tuber infestation in potato stores (Kroschel and Zegarra 2013).

Chemical control. Malathion dust (WHO Class III) is often observed to be sold in developing countries to treat stored tubers. This is especially critical if precautions are not taken properly by farmers and potatoes are stored in living areas. Pyrethroids (e.g., fenvalerate) have shown to be highly effective equally to Btk treatments described above (Kroschel and Koch 1996).

\subsubsection{Pea Leafminer Fly}

\section{Liriomyza huidobrensis Blanchard (Diptera: Agromyzidae)}

Distribution The pea leafminer Liriomyza huidobrensis is an agricultural pest endemic to South America (Fig. 8.4). Since the early 1980s, the pest has been also recorded in many other countries around the world, presumably associated with the global trade of ornamental plants (Mujica et al. 2016; CABI 2012). 

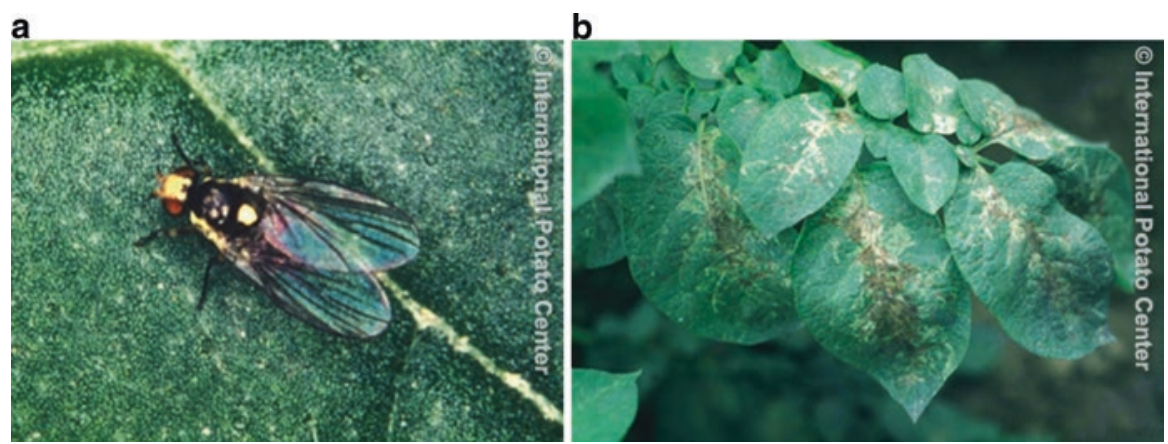

Fig. 8.4 Adult of Liriomyza huidobrensis (a) and symptoms of the larvae infestation on potato leaves (b). (Photo credits: CIP)

Host range L. huidobrensis is highly polyphagous and has been recorded from plants of 14 families (Spencer 1973, 1990). The long list includes potato, bean, pea, alfalfa (Medicago sativa L.), and vegetables such as tomato, celery (Apium graveolens var. dulce (Mill.) Pers.), lettuce (Lactuca sativa L.), pepper (Capsicum annuum var. longum (DC.) Sendtn.), and spinach (Spinacia oleracea L.). In addition, leafminer flies infest many weed species and ornamental plants.

Symptoms of infestation Adults and larvae of L. huidobrensis damage the plant foliage. Adults cause damage by puncturing the leaf surface to feed on the leaf tissue, and to lay eggs. Newly hatched larvae mine into the leaf and feed on the chloroplast-rich mesophyll, making a serpentine mine whose diameter increases as the larva grows. A large proportion of grown larvae remain close to the midrib. Leaf tissue affected by larval mining becomes necrotic and brownish. Highly infested crop fields appear burned (Cisneros and Mujica 1999b).

Impacts on production losses L. huidobrensis is a serious pest of arable crops, vegetables, and ornamental plants under field and glasshouse conditions in many parts of the world. Plant injuries caused by adult and larval activities reduce photosynthesis activity and cause leaf wilting. For potato, yield losses of up to $100 \%$ were reported in Argentina, Chile, and Indonesia (Cisneros and Mujica 1999b). Pest intensity-crop loss relationships for the leafminer fly in different potato varieties indicated that the accumulated foliar injury up to the growth stages of flowering and berry formation produced the highest yield losses in the different potato varieties (Mujica and Kroschel 2013). Economic injury levels in Peru varied according to control costs and commodity values, and potato varieties with longer vegetation period can tolerate higher levels of foliar injury by the leafminer fly before control measures are needed (Desiree: 21-28\%, Revolucion: 34-47\%, Canchan: 31-40\%, Maria Tambeña: 40-53\%, Tomasa: 55-74\%, and Yungay: 40-54\% of foliar injury). 


\section{Methods of prevention and control}

Ecological and economical sound control of the leafminer fly is best realized when based on IPM, which promotes natural enemies in combination with cultural practices and low-toxic insecticides (Mujica 2016; Mujica et al. 2016; Kroschel et al. 2012; Weintraub et al. 2017).

Monitoring pest populations. Counting the number of flies captured in yellow sticky traps monitors adult leafminer fly activity. Counting the number of larvae or fresh tunnels per leaflet by sampling the bottom, middle, and top parts of the plant is used to monitor larval infestation. Both methods can be adapted for decision making and applying an action threshold (AT) to avoid unnecessary applications of insecticides. The AT can be defined as the level of pest population at which control measures should start to prevent the pest population from reaching an economic injury level (EIL, point where economic losses will begin). The AT is typically set below the EIL accounting for the lag time to implement effective control measures. Preemptive insecticidal control is economically not justified until foliar injury exceeds these values (Mujica and Kroschel 2013; Mujica and Kroschel 2018).

Crop management. Healthy, vigorous growing potato plants can better tolerate leafminer damage, particularly during the vegetative phase. Balanced $\mathrm{N}$-fertilization is important as high $\mathrm{N}$-content in leaves promotes leafminer fly development. Continuous food availability by replanting host crops will favor the abundance of the leafminer fly. Rotation with nonhosts is therefore recommended.

Conserving beneficial insects. Leafminer flies are controlled by many beneficial insects, which are either predators or parasitoids. Strategies to conserve beneficial insects can be manifold and include diversified cropping systems, high structural floristic diversity in agricultural landscapes, special weed management practices, and reduced use of broad spectrum insecticides (Mujica et al. 2016).

Classical biological control. It can be an effective strategy in all those regions in which the pea leafminer fly has been unintentionally introduced and where natural enemies of leafminer flies are absent to keep the pest population below economic threshold. The endoparasitoids Halticoptera arduine Walker (Pteromalidae), Chrysocharis flacilla Walker (Eulophidae) and Phaedrotoma scabriventris (Nixon) (Braconidae) were successfully introduced and established in three agro-ecological regions (low, middle, and high altitude) in Kenya (Muchemi et al. 2014; Mujica et al. 2016). Yet, biocontrol of leafminer flies needs to be accompanied by additional, biocontrol-compatible control measures which need to be ultimately integrated into one holistic IPM concept for vegetables that addresses all major pests of the system.

Use of entomopathogenic nematodes. The entomopathogenic nematode Heterorhabditis indica (Rhabditida: Heterorhabditidae) caused 58.7\% of leafminer larval mortality in potato leaves under semi-field conditions. It could be considered as biocontrol-compatible control measure as part of an IPM program for potato and vegetables (Mujica et al. 2013).

Physical control. Yellow attracts leafminer fly adults. The use of mobile $(1 \times 4 \mathrm{~m}$ bands of stick traps which are moved across the fields fixed at tractors or handcarried) and stationary $(50 \times 50 \mathrm{~cm}, 60-80$ traps/ha) yellow sticky traps can 
effectively reduce the leafminer fly adult population. In the Cañete valley of Peru, a cumulative capture of up to seven million adults/ha by using fixed and mobile yellow sticky traps (US\$66.7/ha) resulted in a reduction of the control costs by $55.5 \%$ compared with chemical control (\$200.0/ha), and an average use of six adulticide applications per season (Mujica et al. 2000).

Chemical control. Decisions to use insecticides should be made according to the monitoring results and when the leafminer population is expected to cause economic damage (Mujica and Kroschel 2013). Systemic insecticides with translaminar properties are most effective in controlling leafminer fly larvae. Such insecticides include abamectin and spinosad or cyromazine (Weintraub 2001).

Integrated Pest Management. An IPM strategy based on the use of seed treatment, action threshold, trapping devices and selective application of insecticides showed a higher efficacy to control potato pests including L. huidobrensis than the conventional application of insecticides by farmers in the Cañete valley of Peru. IPM reduced the total quantity of pesticides used per season by $56 \%$ compared to the conventional management, representing a decrease of $69.2 \%$ in the environmental impact. Further, IPM achieved 35\% of higher marketable potato yield than conventional management (Mujica and Kroschel 2018). Leafminer fly is a polyphagous pest and biocontrol-compatible control measures need to be integrated into an IPM concept which considers also other economic pests in potato.

\subsubsection{Andean Potato Weevils}

\section{Premnotrypes suturicallus Kuschel, P. vorax (Hustache), P. latithorax (Pierce) (Coleoptera: Curculionidae)}

The Andean potato weevil complex consists of at least 14 species with 12 in the genus Premnotrypes and two in the genus Rhigopsidius and Phyrdenus. The most important species attacking potato are Premnotrypes vorax, $P$. latithorax and $P$. suturicallus (Fig. 8.5). All Premnotrypes species show sexual dimorphism; the females $(6.8-8.0 \mathrm{~mm})$ are larger than males $(5.6-7.5 \mathrm{~mm})$ (Alcázar and Cisneros 1999).

Distribution The Andean potato weevils (Premnotrypes spp.) are the most serious pests of the potato in the Andean region above $2800 \mathrm{~m}$ above sea level. Its distribution extends from Argentina to Venezuela, covering a mountainous territory of about $5000 \mathrm{~km}$ in length. These weevils are native to the Andes where wild potato and cultivated species are their hosts (Alcázar and Kroschel 2008).

Host range The host range of Andean potato weevils includes only potato and its wild relatives.

Symptoms of infestation The Andean potato weevil, in the larval and adult stages, causes damage to the potato. Adults feed on leaves starting from their edges, marking a very characteristic form of semicircle. When the beetle population is very 


\section{a}
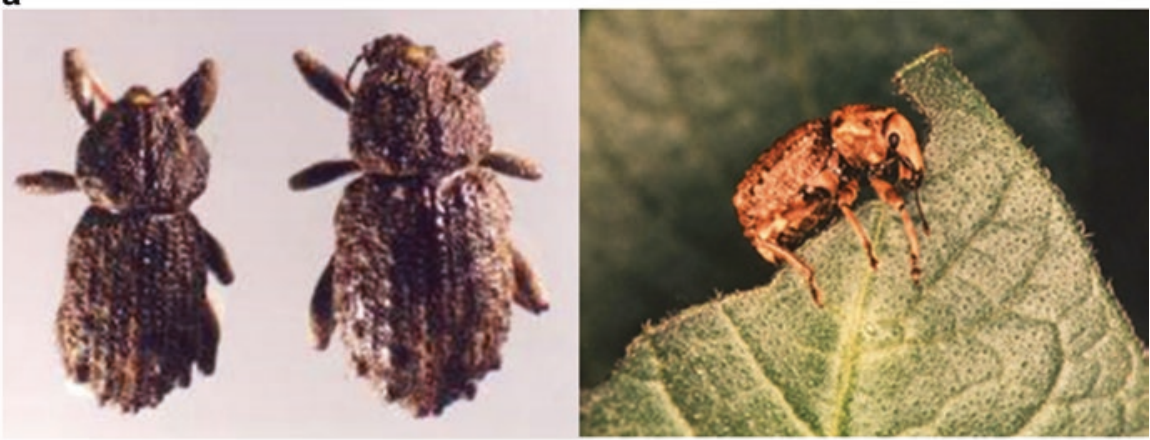

b
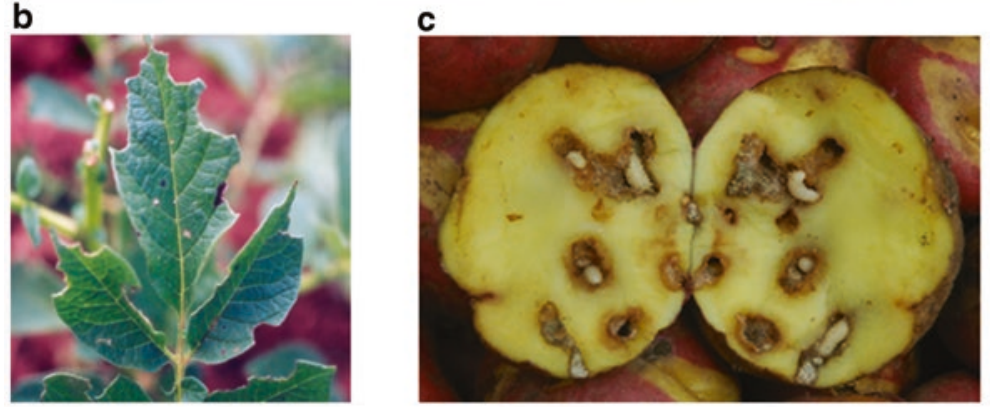

Fig. 8.5 Adult of Premnotrypes suturicallus (a: male, left; female, right), and symptoms of weevil damage on leaves (a, b) and of larvae infestation in potato tubers (c). (Photo credits: CIP)

high, leaves are eaten up to the central leaf vein. Occasionally, adults can also damage on stolons, tubers during formation, and the stem bases. Serious damage to tubers begins when newly emerged larvae penetrate tubers. As the larvae develop, they build characteristic tunnels that are usually filled with excreta. Once the larval stage is complete, the larvae leave the tuber making characteristic circular exit holes (Alcázar and Cisneros 1999; Alcázar and Kroschel 2008).

Impacts on production (losses) Andean potato weevils cause substantial yield losses that seriously threaten Andean farmers' food security. Losses largely vary (16-45\%) even when insecticides are applied. If weevils are not routinely controlled, losses can even reach 80-100\% (Ortiz et al. 1996; Kroschel et al. 2012).

\section{Methods of prevention and control}

(Alcázar and Cisneros 1999; Alcázar and Kroschel 2008; Kroschel et al. 2012).

Cultural control. The main sources of weevil infestations are potato fields of the previous season. It is recommended to maintain community rotation system over distances of about $1 \mathrm{~km}$ between fields. Let the field rest for 3-5 years before planting potato and avoid planting potatoes for two consecutive seasons. Best candidate crops to rotate with include faba bean and barley. Elimination of volunteer potato plants in other crops should be practiced. Early harvest and elimination of crop residues using animals (pigs, sheep) reduces weevil populations in the field. 
Mechanical control. Night collection of adults through plant shaking into buckets.

Physical barriers. It is a method that prevents the adult weevils from entering the field by using a plastic barrier placed around the potato field. It is recommended to install the barriers before or at the time of planting, to prevent the first adults from entering the new fields. Results from the use of plastic barriers studies revealed a higher efficacy for the control of the Andean potato weevil than applications of insecticides (Kroschel et al. 2009).

Plant barriers. Interrupting adult migration into potato fields through plant barriers of tarwi (Lupinus mutabilis Sweet) or mashua (Tropaeolum tuberosum Ruíz and Pavón) has also shown effects of reducing the weevil population.

Chemical control. Generally, the use of insecticides has not demonstrated a consistent efficacy and farmers still experience losses while spraying insecticides 2-3 times.

Natural enemies. Although the weevils are native to the Andes, no specific parasitoids have been identified but predators like carabids are wide-spread and affect the weevil population. Most common species are Blennnidus sp., Notiobia schnusei (Van Endem) and Harpalus turmalinus Er. In addition, entomopathogenic fungi (Beauveria bassiana (Balsamo) Vuillemin) and nematodes (Heterorhabditis sp., and Steinernema sp.) have been identified and used to develop biocontrol strategies (Kroschel et al. 2012; Alcázar and Cisneros 1999; Kaya et al. 2009).

Integrated Pest Management. An IPM strategy consists of the use of plastic barriers in combination with cultural practices; one insecticide application might be required if plastic barriers are used in potato-potato rotations (Kroschel et al. 2011, 2012).

\subsubsection{Potato Psyllid}

\section{Bactericera (ex-Paratrioza) cockerelli (Sulc) (Hemiptera: Triozidae)}

Distribution The potato psyllid Bactericera cockerelli is native to North America and occurs mainly in the Great Plains region of the United States, from Colorado, New Mexico, Arizona, and Nevada, north to Utah. It is also found in Mexico, Guatemala, Honduras, and Nicaragua, and is suspected to be present in other Central American countries, including El Salvador (Fig. 8.6). Following an accidental introduction, B. cockerelli has become widespread in New Zealand (CABI 2016; OIRSA 2016; Rehman et al. 2010).

Host range $B$. cockerelli is found primarily on plants of the family Solanaceae. The psyllid infests and develops on a variety of cultivated and weedy plant species including potato, tomato, pepper, eggplant, and tobacco as well as noncrop species such as black nightshade, groundcherry (Physalis spp.), and matrimony vine (Lycium spp.) (CABI 2016). 

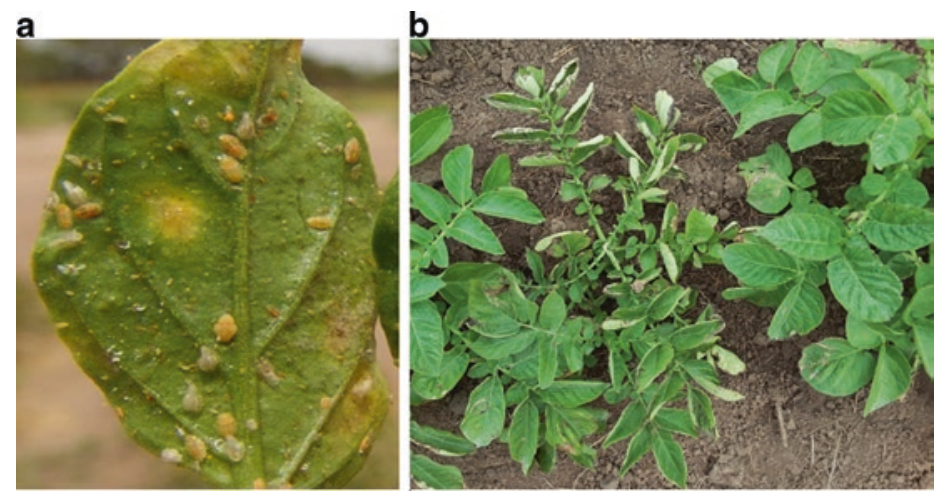

Fig. 8.6 Nymphs of Bactericera cockerelli infesting potato leaves (a) and potato plant affected with potato purple top (b). (Credits: Courtesy of CIP)

Symptoms of infestation Both adults and nymphs feed by sucking the sap of plants. Direct damage is caused by injecting substances that destroy plant cells (toxins). Chlorophyll production is interfered causing leaf yellowing and stuntedness, which together result in a condition known as psyllid yellows. Indirect damage is related to the transmission by nymphs and adults of the bacterium Candidatus liberibacter solanacearum (psyllaurous) that causes infectious diseases known as permanent tomato (PT), potato purple top (PM), and zebra chip. Typical symptoms of potato zebra chip include yellowing and curling of foliage, stunted growth, formation of aerial tubers, shortened and thickened internodes, leaf scorching, reduced tuber size and yield, and early plant death. Belowground, zebra chip is characterized by the presence of collapsed and necrotic stolons, and browning of internal vascular tissues, which, upon frying, exhibits dark brown streaks, hence the term "zebra chip" (Martin 2016; Rehman et al. 2010; Garzón 2002).

Impacts on production losses Potato zebra chip disease is a serious disorder of potatoes that has resulted in millions of dollars in losses to the potato industry. The characteristic symptom is dark striping in the tuber when fried as French fries or potato chips, rendering the infected potatoes unmarketable. It has been determined that $C$. liberibacter is transmitted to potato very rapidly by the potato psyllid, and that a single psyllid per plant can successfully transmit this bacterium to potato in as little as $6 \mathrm{~h}$. This low psyllid density, coupled with a short inoculation access period, represents a substantial challenge for growers in controlling the potato psyllid and preventing zebra chip transmission. Just a few infective psyllids feeding on potato for a short period could result in substantial spread of the disease within a potato field or region (Garzón 2002; Rehman et al. 2010; Munyaneza et al. 2007, 2009). 


\section{Methods of prevention and control}

Monitoring pest population. Early season management of this insect is crucial to minimize damage and psyllid reproduction in the field. Egg and nymphal stages require visual examination of the foliage. Adults can be sampled with yellow traps, which are effective in detecting immigrant populations and must be installed from the beginning of the cropping season. Low populations before or at the start of tuber formation reduce production significantly, but once the tubers are formed plants tolerate direct damage (Henne et al. 2010; Butler and Trumble 2012; Workneh et al. 2012).

Plant resistance. The most valuable and effective strategies to manage zebra chip would likely be those that discourage vector feeding, such as use of plants that are resistant to psyllid feeding or less preferred by the psyllid. Unfortunately, no potato variety has so far been shown to exhibit sufficient resistance or tolerance to zebra chip or potato psyllid.

Biological control. Several predators and parasites of B. cockerelli are known, though there is little documentation of their effectiveness. In New Zealand, fungal isolates of Lecanicillium muscarium (Petch) Zare \& W., Isaria fumosorosea (Wize), and commercial formulations of Beauveria bassiana Balsamo-Crivelli (Vuillemin), I. fumosorosea, and Metarhizium anisopliae (Metchnikoff) Sorokin were successfully tested against nymphs of $B$. cockerelli in laboratory assays and adults and nymphs in greenhouse assays, outperforming a conventional spiromesifen insecticide (Mauchline and Stannard 2013). Commercial formulations of Metarhizium anisopliae $\left(\mathrm{F}^{2} 2^{\circledR}\right.$, Novozymes Biologicals) and Isaria fumosorosea $\left(\mathrm{Pfr} 97^{\circledR}\right.$, Certis USA) significantly reduced plant damage and potato zebra chip symptoms in Weslaco, Texas (Lacey et al. 2011).

Chemical control. Good insecticide coverage or translaminar activity is important because psyllids are commonly found on the underside of the leaves. Because several generations often overlap, caution should be taken when selecting and applying insecticides targeted against the potato psyllid in relation to which life stages are present in the crop and timing of insecticide applications.

Integrated Pest Management. B. cockerelli is often associated with the pathogen Candidatus liberibacter solanacearum and this represents the main challenge in the search for IPM components that can be integrated into the potato crop. Several management strategies have been proposed such as cultural, biological, and chemical control. In New Zealand, the proposed IPM strategy includes careful timing of insecticide applications, incorporating alternative chemicals, integrating treatments with vector monitoring or sampling, establishing action thresholds (although this is difficult for vectors), determining the likelihood of infections throughout the year, and combining chemical applications with resistant or tolerant varieties (Vereijssen et al. 2018). 


\subsubsection{Bud Midge}

\section{Prodiplosis longifila Gagne (Diptera: Cecidomyiidae)}

Distribution Prodiplosis longifila is a polyphagous species only in the Americas (Fig. 8.7). Its origin is unknown. It occurs in North America (first reports from Florida in 1934 and from Virginia in 1990) and South America (Colombia, Peru, and Ecuador). Some publications mention its presence in the "West Indies" but detailed records for individual countries in the Caribbean are not available and a previous record for Jamaica is now considered to be a misidentification (EPPO 2015; Gagné 1986).

Host range $P$. longifila is polyphagous and has been recorded from many plant species. However, economic damage is mainly reported on potato, tomato, pepper, asparagus and to a lesser extent on Tahiti lime (Citrus $\times$ aurantifolia (Christm.) Swingle, Citrus x latifolia (Yu. Tanaka) Tanaka). Lists of host plants include important crops such as onion (Allium cepa L.), watermelon (Citrullus lanatus (Thunb.) Matsum. \& Nakai), melon (Cucumis melo L.), cucumber (Cucumis sativum L.), artichoke (Cynara scolymus var. scolymus L.), soybean (Glycine max L.), alfalfa (Medicago sativa L.), beans (Phaseolus vulgaris L.), castor bean (Ricinus comтиnis L.), and grape (Vitis vinifera L.). Because the identity of the different populations of $P$. longifila has not yet been resolved, some records of hosts previously attributed to $P$. longifila may belong to another species (EPPO 2015).

Symptoms of infestation $P$. longifila is minute in size, but extremely injurious under warm environmental conditions. The larva passes through three stages, with the first and second larval stages being the most harmful and causing damage to flowers and buds of different crops. The larvae of $P$. longifila scrape the epidermal tissues of plant structures using piercing-sucking mouthparts. Feeding on buds distorts growth points and results in winding stems and black appearance. It causes
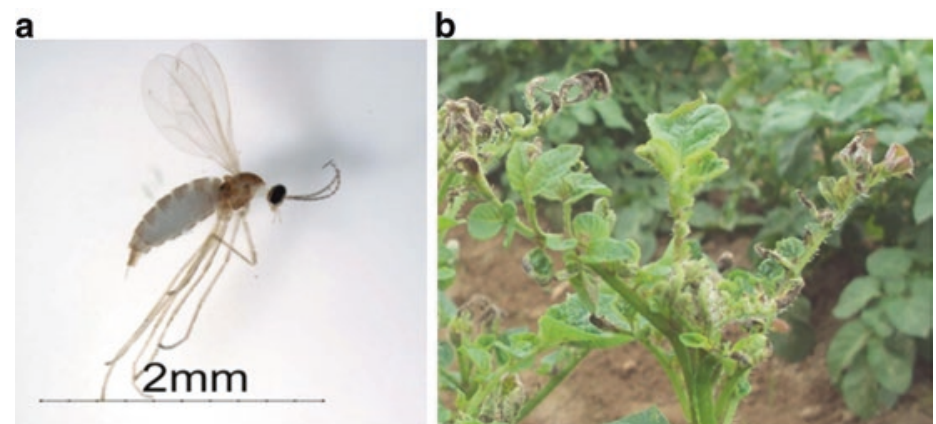

Fig. 8.7 Prodiplosis longifila adult (a), larvae (b) and damage on potato sprouts (b). (Photo credits: CIP) 
flower buds to fall and results in distorted fruit of low quality (EPPO 2015; Hernandez et al. 2015; Sarmiento 1997).

Impacts on production losses $P$. longifila is one of the most important pests of Solanaceae crops (potatoes and other vegetables) and asparagus in the Neotropics causing yield losses $>50 \%$, if not controlled. It affects buds, flowers, and fruits, and causes severe damage to both open and protected crops. During the first 50 days after plant emergence, the bud midge is a critical pest that affects plant growth by destroying both the terminal and lateral buds. However, infestations after flower initiation do not affect potato yields. High temperatures favor the increase in midge population and hence crop damage, which could explain the reduced potato yields recorded during the El Niño phenomenon in Peru (EPPO 2015; Hernandez et al. 2015; Sarmiento 1997).

\section{Methods of prevention and control}

Crop management. Eggs and first instar larvae are in protected places (e.g. under the calyx) and are not visible with the naked eye (Gonzales-Bustamante 1996). Therefore, factors that favor vigorous potato plant growth (appropriate fertilization, healthy seed with vigorous sprouts, irrigation, and biostimulants) prevent pest damage by the rapid growth of buds and the exposure of larvae to dehydration and natural enemies. Management practices to reduce infestation include optimal planting density, orientation of the furrows from east to west to favor insolation, elimination of broadleaf weeds, avoidance of susceptible crops, management of the planting season, and rotation with nonsusceptible crops (Mujica and Kroschel 2018).

Seed treatment. Seed treatment with a systemic insecticide protects buds against initial bud midge infestation from emergence to formation of the first leaves and stems. This is a highly recommended practice since it ensures protection for a period of 35 days during a critical period of the crop, without affecting natural enemies (Mujica and Kroschel 2018).

Chemical control. For a chemical control of this pest, the following should be considered: (a) dusting of sulfur powder on young plants to reduce initial infestation, (b) the use of translaminar or systemic insecticides, (c) dusting of dry powder insecticides at the soil or lower third of the plants, and (d) a combined control of larvae and adults with various active ingredients such as imidacloprid, dimethoate, mixtures of chlorpyrifos and alphacypermethrin, and vegetable and mineral oils (Castillo 2010). Sulfur dust has repellent effects on the adults, but low toxicity to larvae. Treatments with sulfur are more effective in the late afternoon when adults become active and more exposed to the treatments.

Biological control. The most commonly occurring biological control agents are egg and larva parasitoids of the genus Synopeas (Hym.: Platygasteridae), reaching parasitism of 16-20\% (Hernández 2014). Important predators of third instar larvae and pupa are Chrysoperla asoralis Banks, Nabis capsiformis Germar, and Methacantus tenellus Stal.

Biopesticides. In Peru, the entomopathogenic nematode Heterorhabditis sp. (native) showed $80 \%$ pathogenicity in larvae and pupae of $P$. longifila (Pacheco 2015). Mortality of $P$. longifila caused by Metarrhizium anisopliae, Baeuveria 
bassiana, Paecilomices fumosoroseus, and Verticillium lecanii under laboratory and greenhouse conditions was 75 and 69\%, 71 and 73\%, 62 and 50\%, 59 and 44\%, respectively (Reategui et al. 2009). The application of entomopathogens in commercial fields of asparagus showed a reduction of $P$. longilifa pupae by $79.2 \%$ ( $B$. bassiana), 70.8\% (M. anisopliae), 30.4\% (V. lecanii) (Castillo 2010).

\subsection{Major Pests in Temperate Regions}

\subsubsection{Colorado Potato Beetle}

\section{Leptinotarsa decemlineata (Say) (Coleoptera: Chrysomelidae)}

Distribution The Colorado potato beetle Leptinotarsa decemlineta is native to Mexico (Fig. 8.8), but has spread to Central America, most of the United States (except Alaska, California, Hawaii, and Nevada), and to southern Canada. This pest has also been introduced into Europe and parts of Asia (CABI 2017a; Jacques and Fasulo 2015).

Host range Colorado potato beetle is an oligophagous species feeding on about ten species of plants in the family Solanaceae (Alyokhin et al. 2013). These include potato, tomato, and eggplant.

Symptoms of infestation Both adults and larvae are voracious leaf feeders and can completely defoliate potato plants. In rare cases, tubers exposed at the soil surface can also be eaten. Characteristic black and sticky excreta is left on the stem and leaves by the larvae and adults.

Impacts on production losses $L$. decemlineata is one of the most economically important insect pests of potato. Adults and larvae reduce potato tuber yields by

a

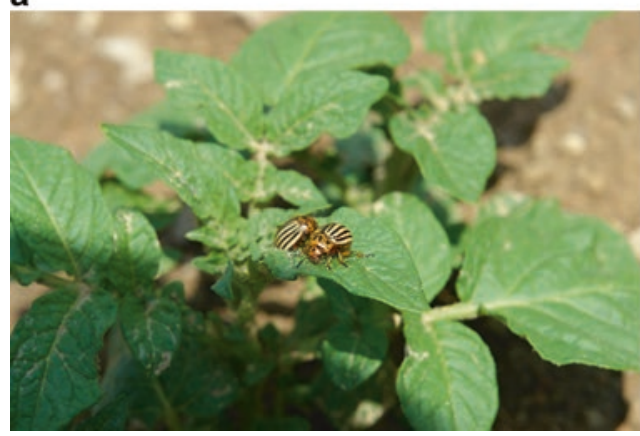

b

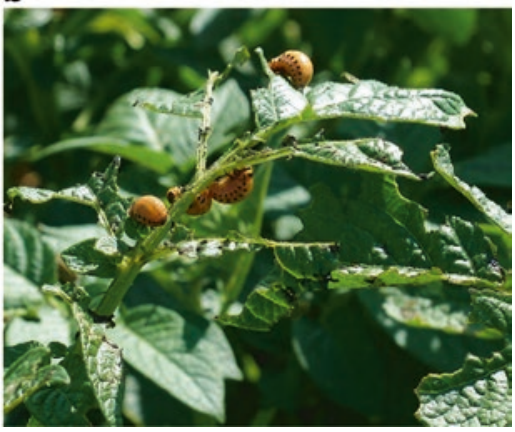

Fig. 8.8 Colorado potato beetle, Leptinotarsa decemlineata, adults (a) and larvae feeding on potato leaves (b). (Photo credits: Andrei Alyokhin) 
devouring foliage. Larvae may defoliate potato plants resulting in yield losses of up to $100 \%$ if the damage occurs prior to tuber formation. Losses in potato are most severe if the incidence of last instar larvae, the most voracious stage, peaks during the time of tuber formation. This species is a huge pest problem and farmers spend millions of dollars each year on insecticides to control it (CABI 2017a; Jacques and Fasulo 2015).

\section{Methods of prevention and control}

IPM programs against this potato pest emphasize reducing insect pest populations by using several control measures, including crop rotation, altered planting dates (to avoid peak pest populations during vulnerable stages of crop development), and use of $B$. thuringiensis toxins or other pesticides when economic injury levels are reached. IPM approaches seek to maximise the impact of naturally occurring biological control agents in suppressing beetle populations (CABI 2017a; Jacques and Fasulo 2015; Laznik et al. 2010; Capinera 2001; Ferro 2000).

Sampling. Entire plants should be examined for above-ground life stages of the insect. Adult beetles are attracted to the yellow color and can be captured with traps. However, traps are seldom used because the various life stages are clearly distinguishable from each other.

Cultural control. The Colorado potato beetle may be managed culturally by crop rotation. Distances of at least $0.5 \mathrm{~km}$ between potato fields are required to provide protection. Beetles initially disperse by walking, so crop rotation and/or trenching can significantly reduce field infestations. Destruction of crop debris after harvest may contribute to reducing beetle populations. Beetle densities are also often lower on mulched potato plots (Alyokhin 2009).

Biological control. While many natural enemies have been identified, they are usually not able to control Colorado potato beetle populations below the economic injury levels. The tachinid fly Myiopharus doryphorae (Riley) may produce high parasitism rates early in the season and prevent the beetles from becoming a serious pest. Also, the entomopathogenic nematodes (Steinernema feltia Filipjev) and the fungus Beauveria bassiana have been reported to offer some control against this pest (Alyokhin 2009).

Biopesticides. Abamectins and spinosins generally provide excellent control of this pest (but see cautionary note on insecticide resistance below). Bacterial insecticides based on delta endotoxin of bacterium Bacillus thuringiensis subsp. tenebrionis are also effective, but they must be applied against the first two instars.

Chemical control. Insecticides are commonly used to control populations of Colorado potato beetle. Resistance to insecticides develops very rapidly in this species. For example, for endrin the first failure was reported after 1 year of its use, while for oxamyl it was observed already within the first year of use (Forgash 1985). Overall, failures were reported to 51 compounds belonging to ten chemical groups and possessing eight modes of action (Alyokhin et al. 2013). 


\subsubsection{European Corn Borer}

\section{Ostrinia nubilalis (Hübner) (Lepidoptera: Crambidae)}

Distribution Ostrinia nubilalis is native to Europe and was introduced into North America near Boston (Massachusetts) in 1917 (Baker et al. 1949). It gradually spread from there to other parts of the United States and Canada. It has also been reported in Asia (China, India, Georgia and Indonesia, middle East (Syria, Israel, Lebanon, Iran, Turkey) and North Africa (Algeria, Egypt, Libya, Morocco and Tunisia) (EPPO 2014; Li et al. 2003). Two races, E and Z that are morphologically indistinguishable exist in both USA and Europe.

Host range The European corn borer is primarily a pest of maize (Zea mays L.), but very polyphagus feeding on host plants from over 17 families but not necessarily being a pest. Economic host crops include potato, pepper, celery (Apium graveolens L.), tomato, beans, hop (Humulus lupulus L.), oat (Avena sativa L.), millet (Panicum spp.), sorghum (Sorghum bicolor L. Moench), cotton (Gossypium arboreum L.), and fruits such as apple (Malus pumilla Miller) and peach (Prunus persica (L.) Batsch L.). Feeding also occurs in ornamental plants and weeds including hollyhock (Alcea rosea L.), mugwort (Artemisia vulgaris L.), pigweed (Amaranthus spp.), and others.

Symptoms of infestation In potato, the most obvious sign of infestation is stem wilt. The entrance hole is in the stem and is easy to locate because of the presence of the excreta that larvae expel while feeding inside the stem. Larval presence can be confirmed by cutting the stem (CABI 2017b). Young larvae tunnel into leaf petioles while older larvae tunnel into the main stem. Larval damage can, however, be confused with that of other stem borers.

Impacts on production losses Potato plants present high tolerance for this insect; fairly high levels of infestation often do not seem to significantly affect tuber yields (Kennedy 1983). Varieties with weak stems are more likely to suffer reduced yields, as affected stems will break more easily during heavy wind- or rain- storms. However, severe infestations may result in considerable crop losses. Also, larval entry holes may facilitate infection by fungal and bacterial pathogens such as Erwinia carotovora.

\section{Methods of prevention and control}

Sampling. Monitoring of adult moth flights is suggested to determine the timing for oviposition and hence if a field is at risk. Sticky traps baited with strain-specific sex pheromones can be used for this purpose. Early infestations can also be more damaging than later ones and scouting for egg masses and observation of damage by the first instar larvae on leaf petioles. It is prudent to be vigilant and to monitor populations in areas where this insect has been known to previously cause damage.

Cultural control. This can involve early planting to escape damage, intercropping with nonhost plants and proper field sanitation involving of ploughing the field at the end of the cropping season. 
Chemical control. European corn borer larvae are not particularly difficult to kill, but pesticide applications, to be effective, must be made before the larvae enter the stem. Pesticide application is recommended only when more than $10 \%$ of the stems show evidence of tunneling (Nault and Kennedy 1996).

Biological control. Bacillus thuringiensis subsp. kurstaki (Btk) and B. thuringiensis aizawai can be successfully applied to target first instar larvae. Alternative control methods include release of commercially available parasitic wasps (Trichogramma nubilale Ertle and Davis and T. brassicae Bezdenko) (CABI 2017b). Other natural enemies that have been used to control the European corn borer include Lydella thompsoni (Herting), Diadegma terebrans (Gravenhorst) and Macrocentrus grandi Goidanich (Baker et al. 1949).

\subsection{Major Pests Globally Present}

\subsubsection{Aphids}

Myzus persicae (Sulzer, 1776), Macrosiphum euphorbiae (Thomas, 1878) (Hemiptera: Aphididae)

Distribution The green peach aphid, Myzus persicae, is thought to have its origins in China, just as its overwintering host plant, the peach (Prunus persica (L.) Batsch) (Fig. 8.9). However, the green peach aphid is highly adaptable and is currently cosmopolitan in distribution. The potato aphid (M. euphorbiae) originated in North America but has spread to the temperate parts of Europe and Asia and is found in all potato growing areas globally (CABI 2017c, d).

Host range Both species are extremely polyphagous, being capable of feeding on several hundred-plant species (Blackman and Eastop 2000).

Symptoms of infestation Aphids can damage potato plants directly by feeding on sap, and indirectly by transmitting various viral diseases. Direct damage. Continuous
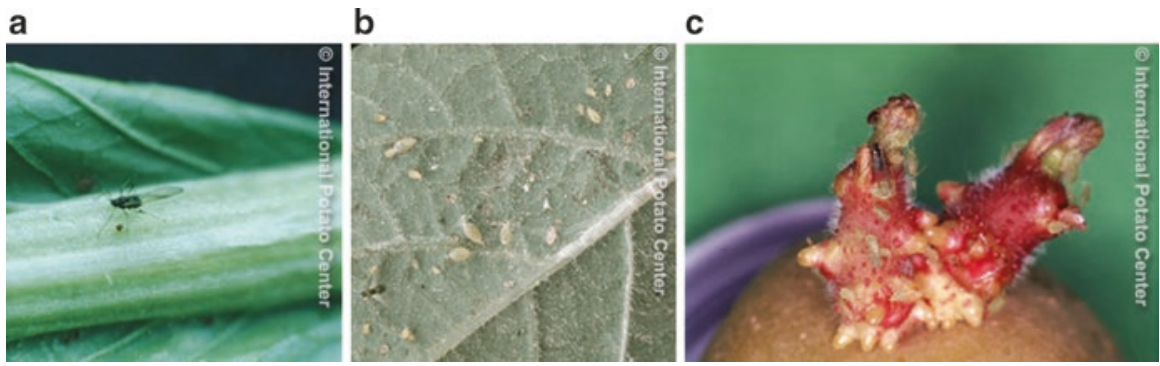

Fig. 8.9 Winged green peach aphid start infestations on potato (a), wingless green peach aphids start colonies under the leaf (b), aphid colonies on potato tuber sprouts in stores (c), where they transmit viruses to seed potatoes. (Photo credits: CIP) 
sucking of sap by large numbers of aphids considerably weakens and slows plant development. Removing sap and injecting toxic saliva causes leaf deformation. The weakened plant produces low quality tubers. During feeding, aphids excrete honey dew which promotes growth of a sooty black mold on plant leaves or stems, hence reducing the photosynthetic area for the plant. Indirect damage. The most important damage caused by aphids in potato is virus transmission. Symptoms of virus infestation vary depending on the virus transmitted. For instance, potato leaf roll virus (PLRV) causes leaf-rolling and tuber stem necrosis in potato. Other PLRV symptoms include thickening, curling, chlorotic spotting and yellowing of the leaves (CABI 2017c, d; Larrain et al. 2003; Salazar 1995).

Impacts on production losses Direct damage: Large build-up in aphid population may result in death of heavily infested plants. Since aphid distribution within potato fields is usually clumped, this results in patches of dead plants, sometimes referred to as "aphid holes." However, this phenomenon is relatively uncommon. In most cases, direct damage by aphids does not affect potato yields. Indirect damage. Most aphid-related damage to potato crops is caused by virus transmission. Potato leafroll virus (PLRV) and potato virus Y (PVY) are the two most important potatoinfecting viruses. Both severely diminish potato yield and quality in most potato-growing areas. PLRV is a persistent virus transmitted exclusively by potato colonizing aphid species. PVY is nonpersistently transmitted by at least 50 different aphid species, most of which probe potato plants with their proboscis, but do not settle nor reproduce on them. M. persicae is the most effective vector of both persistent and nonpersistent viruses. It is also a highly polyphagous species that often moves into potato fields from surrounding crops and noncrop vegetation (CABI 2017c, d; CIP 1996; Larrain et al. 2003; Salazar 1995).

\section{Methods of prevention and control}

Biological control. Various natural enemies of aphids act as efficient biological control agents; among those are different predatory insects (e.g., lady beetles and larvae of green lacewings) and parasitic wasps (Aphidius spp.). Other generalist predators include Orius spp., Geocoris spp., and Nabis spp. Guard rows of flowering vegetation planted within potato fields can provide a habitant for aphid natural enemies (Powell and Pell 2017). Entomopathogenic fungi commonly infect aphids under field conditions and may cause epizootics that significantly reduce aphid densities (Pell et al. 2001). Numerous biological control products that use seven species of entompathogenic fungi (mostly Beauveria bassiana and Lecanicillium spp.) are commercially available for aphid control. Proper timing is very important when using these products because fungal spores are strongly influenced by environmental conditions, such as temperature and relative humidity (Kim et al. 2013).

Biological insecticides. Extracts from garlic (Allium sativa L.), neem (Azadirachta indica A. Juss.), red chili (Capsicum annum L.), pyrethrum flowers (Chrysanthemum sp.), either singly or in mixtures provide some aphid control, especially at an early stage of infestation.

Cultural practices. Weeding and removal of alternative and overwintering hosts such as wild mustards (Brassica spp.), use of wheat straw or white plastic as mulch, 
and intercropping with onion, garlic or coriander (Coriandrum sativum L.) have shown to reduce aphid populations. Planting only high-quality disease-free potato tubers and rogueing out virus-infected plants is recommended for preventing virus damage even in the presence of substantial aphid populations (CIP 1996; Larrain et al. 2003; Sanchez and Vergara 2002).

Chemical control. Insecticides specific to the homopterans such as spirotetramat, flonicamid and pymetrozine have low effect on natural enemies and are therefore good candidates for IPM. To the contrary, use of broad-spectrum insecticides may flair up populations of green peach aphids that recover quicker than populations of their natural enemies. On a small scale, application of potassium-based liquid soap sprays may reduce numbers of potato-colonizing aphids. When practicing chemical control, it is important to remember that green peach aphid has a high propensity for developing insecticide resistance that rivals that of the Colorado potato beetle. Failures have been reported for at least 69 different active ingredients, including all commonly used chemical classes (Alyokhin et al. 2013).

\subsubsection{Whiteflies}

\section{Bemisia tabaci (Gennadius 1989), Trialeurodes vaporariorum (Westwood 1856) (Homoptera: Aleyrodidae)}

Distribution Bemisia tabaci is a common pest in tropical and subtropical regions but is less prominent in temperate habitats (Fig. 8.10). Trialeurodes vaporariorum originated in tropical or subtropical America (probably Brazil or Mexico). Currently, it has become a cosmopolitan pest, with records in every zoogeographic region of the world (CABI 2017e, f).

Host range $B$. tabaci is a highly polypaghous pest. In addition to Solanaceae crops such as potato, tomato, and eggplant, it infests a wide range of other field crops and vegetables; among those are sweetpotato (Ipomoea batatas (L.) Lam.), cotton, beans, cucumber, melon, soybean, cassava (Manihot esculenta Crantz), and many others.

Symptoms of infestation Adult whiteflies can be easily seen on the underside of the leaves. Sucking sap from plant tissue is associated with several physiological plant disorders, such as chlorosis of new foliage. Heavy infestations with hundreds of adult greenhouse whiteflies on the lower surfaces of potato plant leaflets produce whitish spots that subsequently turn dark. As the population increases, sooty mold accumulates on the leaf surface, necrosis develops on the leaf margins, and some leaves curl upward. Necrotic leaf areas expand and coalesce, causing the whole leaf to dry-out. Producing sugar-rich honeydew promotes growth of sooty mold fungi, thus interfering with normal photosynthetic processes. Adult whiteflies transmit a number of viruses, each of which has its own suite of symptoms. For example, potato apical leaf curl virus (PALCV) causes upward or downward curling of leaves. Infection with potato yellow vein virus (PYVV) initially results in bright yellow 

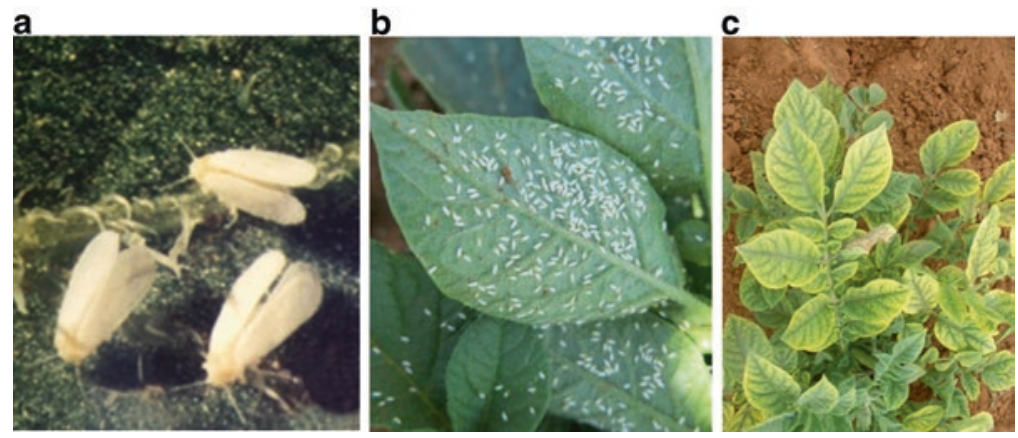

Fig. 8.10 Bemisia tabaci adults on potato leaves $(\mathbf{a}, \mathbf{b})$ and potato plant with symptoms of Potato yellow vein virus (PYVV) transmitted by Trialeurodes vaporariorum (c). (Photo credits: CIP)

veins. As disease progresses, the leaves become yellow, while the veins regain their green color. Infected plants may produce deformed tubers with abnormally large protruding eyes (CABI 2017e, f; Larrain et al. 2003; Sanchez and Vergara 2002).

Impacts on production losses Both direct and indirect damage may result in yield reduction of $40 \%$ or more (Anderson et al. 2005; CABI 2017e, f; Franco-Lara et al. 2013).

\section{Methods of prevention and control}

Monitoring pest populations. Direct observation and use of yellow sticky traps are useful methods for monitoring whiteflies and for early detection and the documentation of relative whitefly abundance over time.

Biological control. Despite abundant research on natural enemies and nonchemical control of B. tabaci few natural enemies have been identified and used in biological control. Nymphs are affected by entomopathogenic fungi such as Verticillium lecanii Zimmerman, Paecilomyces farinosus Holmsk, and $P$. fomosoroseus Wize. $V$. lecanii has been developed as a biopesticide (CABI 2017e, f).

Crop management. Maize can be planted as barrier and/or cucurbits as trap crop for controlling adults and to enhance the development of biological control agents (CABI 2017e, f).

Physical control. Yellow attracts whitefly adults. Stationary yellow stick traps are recommended to be installed at planting around fields to capture whitefly adults migrating from other crops. The use of mobile and stationary yellow sticky traps can effectively reduce white fly adult populations in potato (Cisneros and Mujica 1999c; Mujica 1998).

Chemical Control. Avoid use of broad spectrum insecticides in order not to affect natural enemies. The chitin inhibitor, buprofezin, has shown high efficacy $(>90 \%)$ in controlling immature stages. Soaps (such as potassium soaps) can also be applied on a small scale. Chemical control should be based on using an action threshold of three nymphs per leaf (CABI 2017e, f; Cisneros and Mujica 1999c). 


\subsubsection{Ladybird Beetles}

\section{Henosepilachna vigintioctomaculata (Motschulsky), Henosepilachna vigintioctopunctata (F.) (Coleoptera: Chrysomelidae)}

Distribution Henosepilachna vigintioctomaculata and $H$. vigintioctopunctata are two related and morphologically similar species of phytophagous lady bird beetles that share a common name of a potato ladybird, hadda beetle, or 28-spotted lady bird beetle (Fig. 8.11). H. vigintioctomaculata is common in temperate areas of Asia, including China, Japan, Korea, and Russia. The ranges of both species overlap, particularly in China. However, $H$. vigintioctopunctata prefers warmer climates and is widely distributed in Southeast and South Asia, including Pakistan, and has been introduced to Australia, New Zealand, several Pacific islands, and South America (Katakura 1980; Naz et al. 2012; Xu et al. 2013).

Host range Potato ladybirds are polyphagous species feeding on a variety of plant species. However, most severe damage is usually reported for Solanaceae's crops, including potato (Xu et al. 2013).

Symptoms of infestation Both adults and larvae feed on potato leaves, causing their complete defoliation and eventual death in cases of severe infestation. Feeding by larvae usually starts on the lower sides of infested leaves. Lower epidermis and mesophyll get consumed, while higher epidermis and large veins remain relatively intact (Jackson 2016; Xu et al. 2013). Affected leaves eventually dry up and die. Furthermore, feeding damage may facilitate infections by gray mold, Botrytis cinerea Pers. ex Fr. (Yao et al. 1992).

Impacts on production losses Potato ladybirds can be serious pests of potato. Yield losses have been estimated to reach 10-15\% in normal years, and 20-30\% in the years of heavy infestation (Song et al. 2008). In especially severe cases, complete crop destruction is possible (Jackson 2016).

a

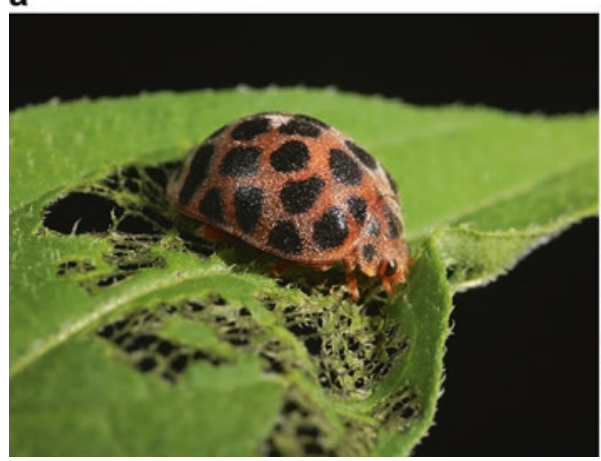

b

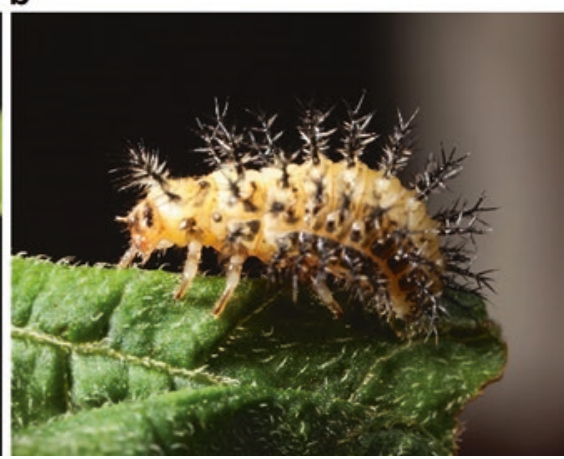

Fig. 8.11 28-spotted ladybird beetle, Henosepilachna vigintioctomaculata, adult (a) and larva (b). (Photo credits: Yulin Gao, Institute of Plant Protection, Chinese Academy of Agricultural Sciences) 


\section{Methods of prevention and control}

Monitoring pest populations. All life stages of potato ladybirds are rather conspicuous, in large part due to their aposematic coloration. Therefore, they can be relatively easily detected by visual observations. Eggs are usually laid in clusters of 20-30 on lower leaf surfaces, thus requiring that scouted leaves are turned upside-down.

Biological control. The parasitic wasp Pediobius foveolatus (Crawford) can parasitize $50-60 \%$ of field potato ladybird populations. In some cases, this reduces damage to economically acceptable levels, and no further control is necessary (Puttarudriah and Krishnamurti 1954; Venkatesha 2006). However, such high parasitism rates should not be taken for granted, and a careful monitoring of ladybird populations is required.

Crop management. Removing and destroying crop residue after harvest deprive resident potato ladybirds of food, thus dramatically enhancing their mortality (Jackson 2016; Xu et al. 2013).

Physical control. Manual destruction of potato ladybird beetles is recommended for small potato plots (Xu et al. 2013). Success of this approach is facilitated by the tendency of ladybird adults to aggregate at overwintering sites outside of potato fields. Adult ladybird beetles are strongly phototactic (Zhou et al. 2015). Therefore, light traps can be used to reduce their numbers. However, feasibility of this approach remains to be investigated. Also, light traps attract a wide variety of insects, including beneficial species (Zhou et al. 2015).

Biological insecticides. Some botanical products, such as azadirachtin, have a good efficacy for ladybird management (Ghosh and Chakraborty 2012; Jeyasankar et al. 2014). Also, the entomopathogenic fungi Beauveria bassiana and Metarrhizium anisopliae (Vishwakarma et al. 2011) and Bacillus thuringiensis (Song et al. 2008) are used.

Chemical Control. Potato ladybird beetles can be easily killed by common broad-spectrum insecticides, which remains unfortunately the most common approach to controlling these pests (Xu et al. 2013).

\subsection{Minor Pests Globally Present}

\subsubsection{Cutworms}

\section{Agrotis ipsilon (Hufnagel, 1776), Peridroma saucia (Hübner, 1808), Agrotis segetum (Denis \& Schiffermüller, 1775) (Lepidoptera: Noctuidae)}

Distribution Cutworms are larvae of several noctuid moth species which are cosmopolitan (Fig. 8.12). Most widely distributed are the black cutworm (Agrotis ipsilon), the variegated cutworm (Peridroma saucia) and the turnip moth (Agrotis segetum). Their origin is uncertain but specimens which were used to describe $A$. ipsilon in 1766 were collected from Austria. 

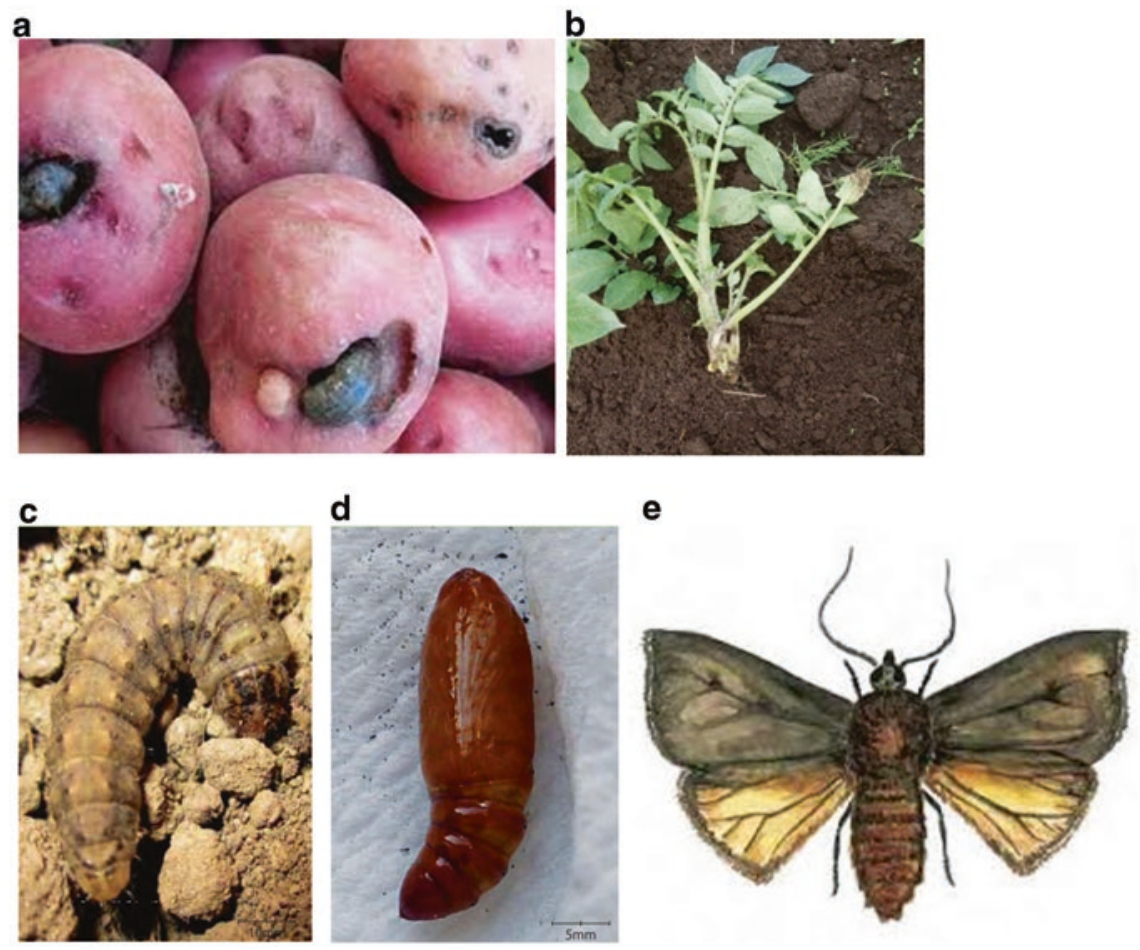

Fig. 8.12 Cutworm larval damage on potato tuber (a), and freshly cut potato plant (b). Cutworm larva (c), pupa (d) and adult (e) of Agrotis ipsylon. (Photo credits: CIP)

Host range Cutworms are polyphagous and have been reported as a pest on nearly all vegetable crops and some cereals. It's a pest in potato, maize, alfalfa, clover (Trifolium L.), cotton, rice, sorghum, strawberry, sugar beet, and tobacco. The larvae sometimes prefer to feed on weeds such as bluegrass (Poa pratensis L.), curled dock (Rumex crispus L.), lambsquarters (Chenopodium album L.), yellow rocket (Barbarea vulgaris W.T. Aiton); and redroot pigweed (Amaranthus retroflexus L.). Considerable damage has also been observed among shrubs and trees such as linden (Tilia sp.), wild plum (Prunus sp.), crabapple (Malus sp.), and lilac (Syringa vulgaris L.). Cereals such as oats (Avena sativa L.), barley (Hordeum vulgare L.), sorghum, maize, and wheat (Triticum spp.) are also affected.

Symptoms of infestation The cutworm larvae remain in the soil at the base of the plant during the day. At night, some species cut down the stems of young potato plants, while other species climb the plants and feed on their leaves. Old instar larvae can occasionally tunnel into potato stems disrupting plant growth. Tubers closer to the ground surface may suffer occasional damage. In a single night, as single larva can cut down several potato plants.

Impacts on production losses Cutworms if not detected early and during outbreaks can cause up to $100 \%$ crop loss through cutting down of potato plants. 


\section{Methods of prevention and control}

Monitoring. Use of sex pheromones in white and yellow traps during spring are quite effective in predicting attacks. Baited traps can also be used to monitor larva populations in the field (Sanchez and Vergara 2002).

Cultural control. Deep tillage exposes larvae and pupae to the action of natural enemies and may crash them mechanically. Weed control also aids in reducing cutworm damage by reducing the sites for egg-laying because these insects infest a wide range of host plants. Properly covering tubers during hilling impedes larval access to the tubers. Late harvest results in a greater damage of tubers. Hand picking of the larvae very early in the morning is the most commonly used method for cutworm control among smallholder farmers in Africa. Fallowing and crop rotation with none host plants such as bluegrass, onion, garlic, peppermint (Mentha piperita L.) and coriander can also reduce cutworm populations as well as habitat management and farming practices that conserve populations of existing natural enemies. Trap cropping using susceptible host plants such a sunflower or cosmos (Cosmos sp.) has also been used in combination with daily killing the trapped cutworm larvae. Flooding of the infested field between crops can also kill the cutworm larvae. Sticky substances such as mollasses and saw dust can also be spread at the base of the plant to trap the cutworm larvae.

Transgenic plants. Several transgenic crops (maize, tobacco, wheat, cotton and maize) have been reported to be resistant to cutworm damage. The genes responsible for resistance against A. ipsilon include Bacillus thuringiensis cry1Ac gene (Bt), barley trysin inhibitor (Bti-cme) and cowpea trypsin inhibitor (CpTi). Preliminary results of genetically modified potatoes show that feeding larvae on leaves which expresses Cry3 Aa affect larvae by being toxic, and also that $\mathrm{Bt}$ potatoes curb the growth and reproduction of the adults of Agrotis ipsilon.

Biological control. Cutworms are hosts for numerous parasitoid wasps and flies, including species of Braconidae Cotesia ruficrus (Haliday), Snellenius manilae (Ashmead), Ichneumonidae Tenichneumon panzer (Wesmael), Tachinidae Bonnetia comta (Fallen), Euplectrus plathypenae and Eulophidae, with rates of parasitism as high as $75-80 \%$. Up to $60 \%$ of cutworm larvae have been reported to be killed by an entomopathogenic nematode, Hexamermis arvalis in central USA. Entomopathogenic nematodes that have been used in the control of A. ipslon larvae include Steinernema glaseri, S. riobrave and Steinernema carpocapsae (Sanchez and Vergara 2002).

Biopesticides. Extracts from the following plants have demonstrated to be toxic to the larvae of A. ipslon: Nerium oleander L. leaves, neem leaves and seeds, Melia azedarach L. fruits, Bassia muricate (L.) Asch., Lantana sp., Parthenium sp., Hyptis sp., Ipomoea carnea Jacq., Tephrosia nubica (Boiss.) Baker, Bidens pilosa L. and Rumex nepalensis Spreng. roots (CABI 2018a).

Chemical control. Spotted or localized field infestations by cutworms are typical, calling for focused subsurface soil insecticide applications. The use of toxic baits is recommended because of its specificity against these insects and because it does not markedly affect the biological control agents. Toxic baits prepared as a mix of bran, molasses, water, and insecticide should be applied at the base of plants at dusk (CIP 1996; Larrain et al. 2003). 


\subsubsection{Armyworms}

Spodoptera eridania (Stoll), Spodoptera frugiperda (J E Smith), Mamestra configurata (Walker), Spodoptera ornithogalli Guenée, Copitarsia decolora (Guenée), Feltia spp., (Lepidoptera: Noctuidae)

Distribution Spodoptera frugiperda is distributed in North, Central, and South America, Africa, and India (CABI 2018a) (Fig. 8.13). S. frugiperda is on the EPPO A1 list of quarantine pests and is intercepted occasionally in Europe on imported plant material (CABI 2018b). S. eridania occurs throughout southern USA, Central and South America, and the Caribbean. It is not established in Europe (CABI 2018c). Mamestra configurata is restricted to North America (Canada, USA, Mexico) (CABI 2018d).

Host range Army worms feed on a wide range of crops and are important pests especially in cereals. However. they have also been reported to feed on potato in absence of the primary hosts (Strand 2006).

Symptoms of infestation Armyworms are mainly forage feeders and feed during the day, do not make burrows, and may migrate in mass into potato fields from adjacent crops. They also feed on tubers that are exposed on the surface or accessible through cracks in the soil (CIP 1996; Larrain et al. 2003; Sanchez and Vergara 2002).

Impacts on production losses Armyworms can cause up to 100\% crop defoliation of potato plants. Some defoliation from armyworms can be tolerated. Keeping defoliation between $10-15 \%$ will generally prevent yield losses.

Methods of prevention and control It is recommended to make suitable soil preparations that expose the pupa of the insect to environmental conditions and predators. There is biological control based on the use of natural enemies of eggs and larvae, such as Tachinid insects, Inchneumonids, Trichogramatids, the fungus

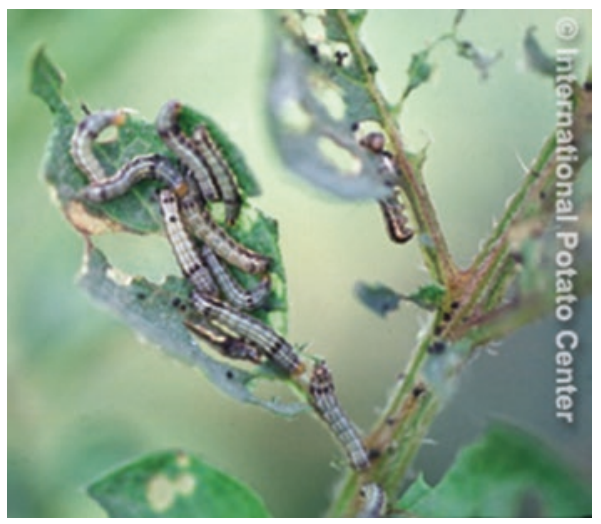

Fig. 8.13 Spodoptera frugiperda larvae infesting potato leaves (a). (Photo credits: CIP) 
Zoophthora radicans affecting larvae, among others (Larrain et al. 2003). Spotted or localized field infestations are typical, calling for focused insecticide treatments. Toxic baits prepared as a mix of bran, molasses, water, and insecticide should be applied at the base of plants at dusk (CIP 1996).

\subsubsection{Wireworms}

Agriotes lineatus (L.), A. vobscurus (L.), A. sputator (L.)., Athous haemorrhoidalis (F.), Conoderus rudis (Brown), C. vespertinus (Fabricius), Ctenicera pruinina (Horn), C. cuprea (Fabricius), Melanotus communis (Gyllenhal) (Coleoptera: Elateridae)

Distribution Wire worms are the larvae of click beetles (Fig. 8.14). Over 39 species in 21 genera of wireworms have been reported to attack potato. Wireworms are found throughout the world, and species vary greatly among regions. While in the $\mathrm{UK}$, the three most important pest species in potato are Agriotes lineatus, A. vobscurus, and A. sputator, in the US, these are Limonius canus LeConte, Limonius californicus (Mannerheim), A. lineatus, A. obscurus L. and A. sputator.

Host range Grasses are the main host but they also attack potato, asparagus, carrot (Daucus carota subsp. sativus (Hoffm.) Schübl. \& G. Martens), sugar beet (Beta vulgaris $\mathrm{L}$.) and leek (Allium ampeloprasum $\mathrm{L}$.)

Symptoms of infestation Wireworms are frequent pests in temperate climates, but less so in warm tropical areas. Thin, lustrous larvae with small thoracic legs live underground and may be up to $25 \mathrm{~mm}$ long. The larvae can borrow deeply inside tubers, and spend considerable time over there producing irregularly shaped tunnels in tubers (CIP 1996; Larrain et al. 2003; Sanchez and Vergara 2002).

Impacts on production losses Wireworms may injure potatoes by feeding on the seed piece resulting in weak stands, but most of their damage is caused by tunneling

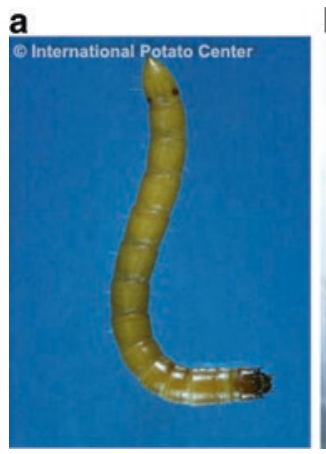

b

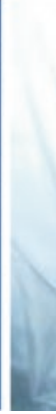

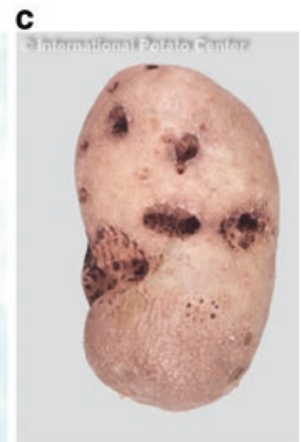

Fig. 8.14 Wireworm larvae (a, b) and larval damage on potato tuber (c). (Photo credits: CIP) 
into tubers, which reduces yield quality. Wireworm tunneling also creates an entry point for certain plant pathogens, eventually leading to tuber rot. In some years and regions of the U.S., up to $45 \%$ of the total potato tuber harvest has been downgraded or rejected outright because of wireworm injury, resulting in substantial economic loss (Steele 2011).

\section{Methods of prevention and control}

Monitoring. Avoid growing potatoes in wireworm infested fields. Plan and utilize a range of risk assessment methods such as pheromone and bait trapping, as well as soil sampling to confirm the status of each field. In arable rotations, plough-based cultivation may help to reduce wireworm populations (Larrain et al. 2003).

Cultural control. Wireworms feed on the roots of various crops, particularly grasses. Consequently, before planting potatoes in pasture areas, the soil borne wireworm larvae population must be reduced by proper plowing and rotation with other crops that require frequent tilling. Keeping potato fields free from weeds has also been reported to reduce wireworm populations.

Biological control. Currently there are no commercial biological control agents available for controlling wireworms, although some strains of the insect-pathogenic fungus Metarhizium anisopliae have shown promising results under experimental conditions (Kabaluk et al. 2005).

Chemical control. Insecticides applied to soil may be required in certain circumstances. To be effective, insecticides for the control of wireworms need to be incorporated into the soil at planting and remain active during the cropping season (Parker and Howard 2001).

\subsubsection{Flea Beetles}

\section{Epitrix spp. (Coleoptera: Chrysomelidae)}

Distribution Epitrix spp. is a genus of many flea beetles that are known to feed upon members of the Solanaceae family. Epitrix tuberis Gentner (1944) and E. cucumeris (Harris 1851) are common pests of potato in North America (Malumphy et al. 2016) (Fig. 8.15). A nonnative pest of potato recently established and causing significant economic damage in Portugal and Spain was identified as Epitrix papa

a

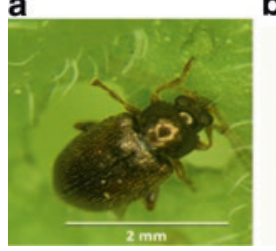

b

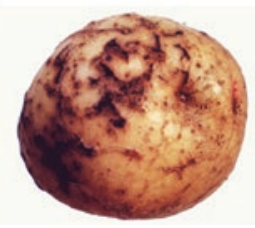

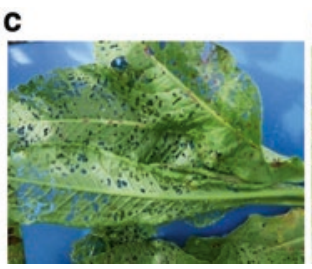

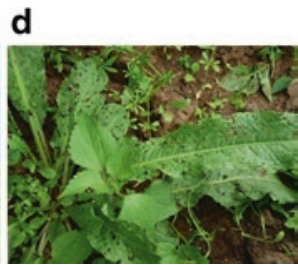

Fig. 8.15 Adult damage on potato leaves (a) and larval damage on potato tuber (b). Heavy adult damage and infestation on a weed in potato field in Kabale, Uganda (c, d). (Photo credits: CIP) 
sp. n. and included in the list of quarantine pests in Europe (Eyre and Giltrap 2013; Malumphy et al. 2016; Sanchez and Vergara 2002). Epitrix yanazara Bechyné (1959) was the major economic important species in the central highlands of Peru (Kroschel et al. 2012) which is a region with a high diversity of flea beetles (Furth et al. 2015).

Host range The host range comprises potato, tomato, eggplant, tobacco as well as weeds of the family Solanaceae.

Symptoms of infestation Flea beetles are small beetles and jump easily in the foliage of plants. Their feeding results in characteristic circular holes less than $3 \mathrm{~mm}$ in diameter. Larvae that feed on roots, stolons, and tubers also cause damage. They bore the tubers superficially or scratch the skin, thus facilitating penetration of pathogenic fungi (CIP 1996; Larrain et al. 2003; Sanchez and Vergara 2002).

Impacts on production losses The flea beetles are considered one of the most serious pests threatening the entire EPPO region. In North America, they are ubiquitous. In cases of severe infestation, defoliation by adults may cause leaves to dry completely, thus affecting photosynthesis and plant yield. Larval damage makes tubers become unviable for sale, and the destruction of the roots can result in plant death (Eyre and Giltrap 2013; Malumphy et al. 2016; Sanchez and Vergara 2002). In Peru, populations increased severely above economic thresholds if no pesticides were applied (Kroschel et al. 2012).

\section{Methods of prevention and control}

Cultural control. Crop rotation. Removal of host weeds and appropriate soil management to ensure vigorous potato plants contribute to reducing flea beetle populations.

Chemical control. Many insecticides that are used to control other insect pests of potato are also effective against flea beetles. Potato plants withstand some foliage damage beyond which insecticides are required (CIP 1996; Larrain et al. 2003; Sanchez and Vergara 2002).

\subsubsection{White Grubs}

Phyllophaga spp., Anomala spp., Popillia japonica Newman, Anomala orientalis Waterhouse, Holotrichia javana Brenske, Holotrichia oblita Faldermann, Temnorhynchus coronatus (Fabricius), Holotrichia longipennis Blanchard, Brahmina coriacea Hope, Melolontha melolontha Linnaeus (Coleoptera: Scarabaeidae)

White grubs are found in many genera in the family Scarabaeidae.

Distribution Scarab beetles and thus white grubs are found worldwide.

Host range White grubs are polyphagus and feed on over 1000 plant species including field crops such as potato, sweetpotato, maize, asparagus, and soybean; 

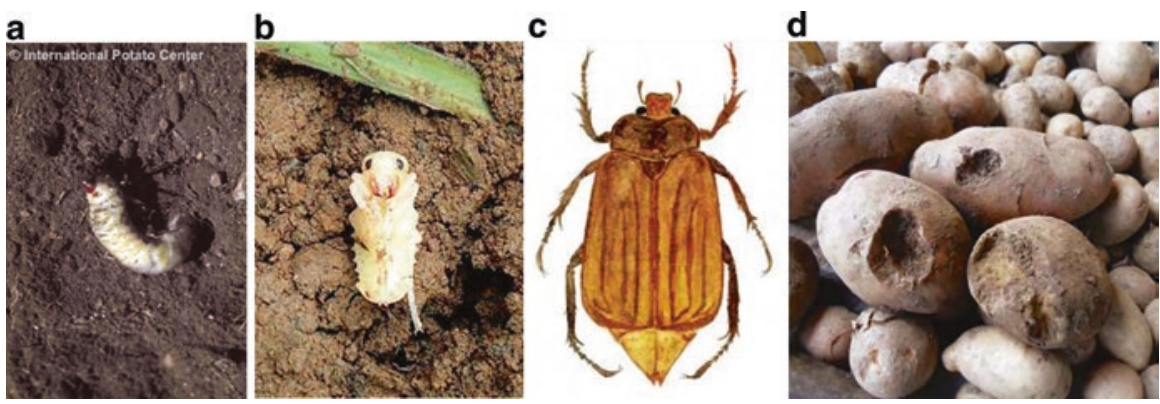

Fig. 8.16 Typical white grub larva (a) and pupa (b) of the genus Phyllophaga. Adult of Melolantha melolantha (c) and damage of larvae in potato tubers (d). (Photo credits: CIP)

fruits such as apple, peach, grape, as well as trees and ornamentals (Pathania and Chandel 2016; Visser and Stals 2012; Misra and Chandel 2003) (Fig. 8.16).

Symptoms of infestation White grubs are the larvae of relatively large beetles. The damage is done mainly by the grubs which remain in the soil. They damage the plant by feeding on roots, underground stem parts, stolons, and tubers. Earlier instars feed on the roots and may cause the plants to dry up. After tubers are developed, the grubs switch to feeding on them, leaving large holes (BioNET-EAFRINET 2011; CIP 1996; Sanchez and Vergara 2002; Visser 2012).

Impacts on production losses Economic damage results mostly from larval damage to potato tubers. Severe damage usually occurs when planting potato in former pasture or grazing fields, which are preferred habitats for white grubs, and on no-till or reduced-till land (CIP 1996; Larrain et al. 2003; Sanchez and Vergara 2002). Yield losses of 40-80\% have been reported in India (Pathania and Chandel 2016; Misra 1995).

\section{Methods of prevention and control}

Cultural practices. Deep tilling exposes white grubs to adverse environmental conditions such as sunlight and frost, and to predatory vertebrates. Ensuring proper drainage in the field will reduce white grub populations since they prefer moist soil, especially with high content of decaying organic matter. Potato should not be planted directly following pasture, grass, or several successive years of cereals and/ or corn. Crop rotation is an effective control method when potato is rotated with resistant or less susceptible crops, such as deep-rooted legumes (e.g., alfalfa, cowpea, and pigeon peas) and Allium crops (onions, garlic). Strips of African marigold (Tagetes sp.), sunflower (Helianthus annuus L.), and castor can be used as trap crops. Allium crops also repel adult beetles from laying eggs (Larrain et al. 2003; BioNET-EAFRINET 2011).

Biological control. Natural enemies that control white grubs include parasitic wasps in the genera Tiphia, Myzinum (Hymenoptera: Tiphiidae), and Pelecinus polyturator Drury (Hymenoptera: Pelecinidae), and the fly, Pyrgota undata Wiedemann (Diptera: Pyrgotidae). Spores of the pathogens Bacillus popilliae, 
B. lentimorbus, and Metarhizium anisopliae can be used to inoculate the soil. Nematodes species such as Steinernema sp. and Heterrorhabditis sp. can also be effectively used against white grubs (Sanchez and Vergara 2002).

Chemical control. This pest is not easily controlled with insecticides. Chemical treatment on grubs must be done when they are young, as older larvae are more robust and move to a greater depth as they develop (Gupta and Gavkare 2014).

\subsubsection{Mites}

\section{Tetranychus urticae C. L. Koch, T. evansi Baker \& Prichard, Polyphagotarsone- mus latus (Banks) (Arachnidae: Trombidiformis, Tarsonemidae)}

Distribution The origin of the tomato or tobacco red-spider mite Tetranychus evansi is Brazil. The pest was accidentally introduced into Southern Africa during the 1980s. The two spotted- or red-spider mite Tetranychus urticae and the broad mite Polyphagotarsonemus latus are widely distributed in both tropical and subtropical areas of the world (CABI 2017g, h) (Fig. 8.17).

Host range Mites are polyphagous. Major hosts are potato, tomato, tobacco, pepper, eggplant, pumpkins and squashes (Cucurbita pepo L.), cucumber, watermelon, celery, maize, beans, strawberry (Fragaria $\times$ ananassa), cotton, citrus, papaya (Carica papaya L.) (Hazzard 2013; Landis and Davis 1947; Goftishu et al. 2016).

Symptoms of infestation T. urticae and related mites are generally known as red spiders, although red is not always their characteristic color. Mites are extremely small, almost microscopic, and feed on the cellular matter of leaves. Chlorotic spots caused by mites give leaves a tan coloring, whereas high infestation will cause leaf and plant wilting. P. latus attacks sprouts and tender leaves, deforming them. Damage to growing plants is particularly severe. The white mite colonies are located on the underside of the young leaves and on the buds. The infested plants take a dark
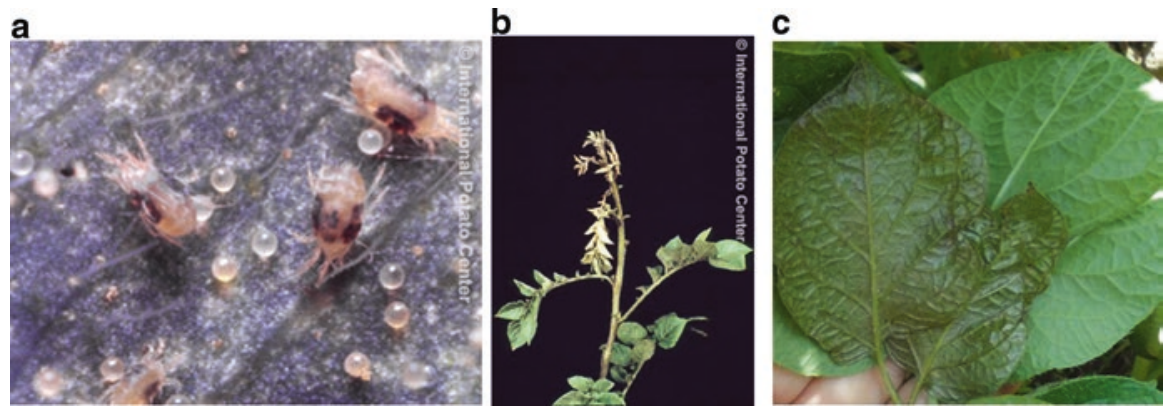

Fig. 8.17 Tetranychus urticae feeding on a potato leaf (a), and symptoms of white mite feeding causing deformation of buds and tender leaves (b) and toasted appearance on the underside of a potato leaf (c). (Photo credits: CIP) 
to moderate green coloration and develop a somewhat leathery appearance. Heavy infestation may result in plant death (CIP 1996; Larrain et al. 2003; Sanchez and Vergara 2002; Landis and Davis 1947).

Impacts on production losses Plants with severe damage of $P$. latus do not form tubers and remain very small. When infestations occur in an intense and violent way they can cause the destruction of entire crop field. In the same way, attack by hundreds or thousands of red spider mites can cause thousands of lesions, thus can significantly reduce the photosynthetic capability of plants (CIP 1996; Larrain et al. 2003; Sanchez and Vergara 2002).

\section{Methods of prevention and control}

Monitoring. Mite infestations normally begin at boundaries of the potato fields especially those neighboring fields of preferred host plants such as maize, alfalfa, and mint. Stressed potato plants tend to be more susceptible. Mites can build high populations in a very short time during hot (above $30^{\circ} \mathrm{C}$ ) dry seasons. Constant visual monitoring and early detection is key. Check on the underside of leaves that show symptoms of nutrient deficiency (CABI 2017g, h).

Cultural practices. Sprinkler irrigation helps to limit mite damage by increasing the humidity (above 60\%) on plant leaves, thus making conditions less favorable for mites. Proper field sanitation is done through removal of infested plants and volunteer crops (CIP 1996; CABI 2017g, h).

Natural control. Often mites are kept under control by their natural enemies, including predatory thrips, lacewings, gall midges (Feltiella acarisuga Vallot) and ladybird beetles (Stethorus punctillum Weise) and predatory mites (Phytoseiulus persimilis Athias-Henriot, Neoseiulus californicus (McGregor), Amblyseius andersonii Berlese, Galendromus occidentalis Nesbitt, Mesoseiulus longipes, and Hypoaspis miles Berlese (Pundt 2007). Mites become primary pest when natural enemies are destroyed by insecticide applications to control other insect pests. So, avoid use of nonselective pesticides which reduce predatory mite populations.

Biopesticides. Plant extracts such as azadirachtin (neem oil), or from cotton seed, soybean, clover, garlic, rosemary (Rosemarinus officinalis L.), and pyrethrum have shown some efficacy against red spider mites (CABI 2017g, h).

Chemical control. When control measures are required, usually a single application of an acaricide is sufficient especially when populations are still low $(<$ five mites per plant). In some cases, focal treatments are recommended using either soap, sulphur, Bifenazate, abamectin, spirotetramat, and spiromesifen (Hazzard 2008).

\subsubsection{Thrips}

\section{Frankliniella occidentalis (Pergande), Thrips tabaci Lindeman (Thysanoptera, Thripidae)}

Distribution The western flower thrips Frankliniella occidentalis originated in western North America and has since become a major pest on many crops across the 

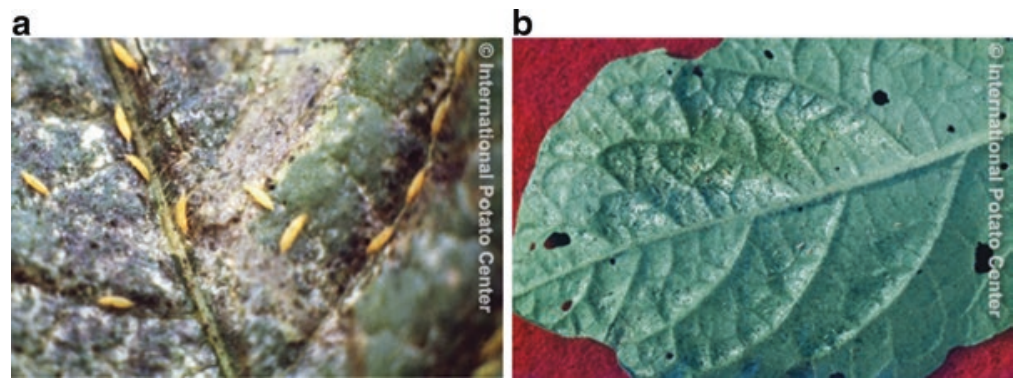

Fig. 8.18 Pale or brown nymphs and darker adults of Frankliniella occidentalis on the underside of potato leaves (a), and symptoms of thrips feeding causes silvering on underside of a potato leaf (b). (Photo credits: CIP)

US and around the world (Fig. 8.18). The onion thrip Thrips tabaci is thought to have originated in the Mediterranean region but is now found on all continents except Antarctica.

Host range F. occidentalis feeds on more than 200 crops in over 50 genera and this includes vegetables, fruit trees, and ornamentals.

Symptoms of infestation Thrips can cause major damage mainly during dry climatic conditions. Because of heavy feeding, potato leaves develop a silver or chlorotic dotting of the tissues and become deformed. The silver color is due to the emptying of the cells (CIP 1996; CABI 2017i, j; Learmonth 2017).

Impacts on production losses Thrips are minor pest of potato. Some species are vectors for tomato spotted wilt virus (TSWV), with western flower thrips (F. occidentalis) as the most important virus vector. The virus reduces crop yield and tuber quality (CABI 2017i, j).

\section{Methods of prevention and control}

Cultural practices. Thrips feed on a wide range of plants, including weeds from which they can invade potato crops. Therefore, weed control is a good management strategy for this pest. Susceptible crops (onion, tomato, corn, artichoke, and pumpkin) should not be planted next to a potato crop. Any plants showing tomato spotted wilt virus symptoms should be removed (CIP 1996; CABI i, j; Learmonth 2017).

Behavioral control. Yellow or blue (especially for F. occidentalis) sticky traps can be used to monitor the presence of thrips.

Biological control. Various species of the worldwide anthocorid genus Orius are used in biological control against thrips, and these bugs are important as predators in many natural populations. Amblyseius swirskii Athias-Henriot and Neoseiulus cucumeris Oudemans are two of the most widely used predatory mites in the biological control of $F$. occidentalis. Fungal pathogens and nematodes, such as Beauveria bassiana and Steinernema feltiae, are also being used commercially. Parasitoids include Ceranisus menes Walker for the western flower thrip (CABI 2017i, j).

Chemical control. Low to medium toxicity pesticides used against thrips include Spinosad, Spinetoram, and Abamectin (Bentley and Rice 2015). 


\subsubsection{Tomato Tuber Moth}

\section{Tuta absoluta (Meyrick) (Lepidoptera: Gelechiidae)}

Distribution The tomato leaf miner, Tuta absoluta, was first identified in Peru by Meyrick in the year 1917 from samples collected in Huancayo (3200 m above sea level) (Fig. 8.19). Since then, it has been recorded in all South American countries. The pest is predominantly found in areas below $1000 \mathrm{~m}$ asl. It was first introduced into Europe in Spain in 2006, from where it is believed to have spread to other European countries. Its range has expanded considerably to Asian and African countries in recent years (CABI 2017k).

Host range Hosts of T. absoluta are the cultivated Solanaceae tomato, potato, eggplant, sweet cucumber (Solanum muricatum L.), and tobacco. Other cultivated host plants are slender amaranth (Amaranthus viridis L.), groundcherry, and the Johnson grass (Sorghum halepense (L.) Pers.). Noncultivated Solanaceae hosts include a wide range of weeds such as Lycopersicon hirsutum Dunal, Lycopersicum puberulum $\mathrm{Ph}$, Solanum americanum Mill., S. bonariense L., S. elaeagnifolium L., S. hirtum, S. lyratum, S. nigrum L., S. puberulum, S. sisymbriifolium Lam., S. saponaceum, Datura stramonium L. (jimsonweed), D. ferox L., Nicotiana glauca Graham, Lycium chilense (Bertero), Lycopersicon pennellii var. puberulum (Correll), Solanum dubium Fresen, and Solanum puberulum Phil.

Symptoms of infestation On potato, T. absoluta attacks aerial parts and occasionally tubers. Foliar damage is a result of mine-formation within the mesophyll by the feeding larvae. The newly emerged larvae are quite mobile and begin their feeding by building galleries on the leaflets. Depending on the place of oviposition, a larva may penetrate leaf mesophyll, leaf petiole, and young shoots. The mines expand as

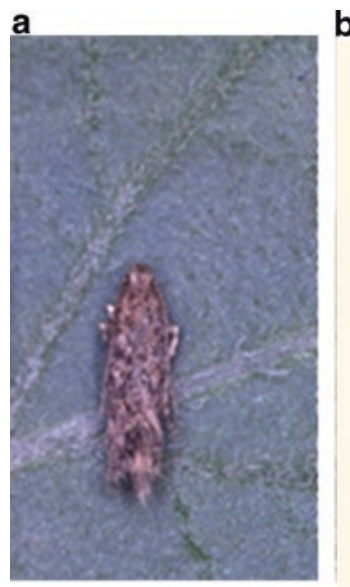

b

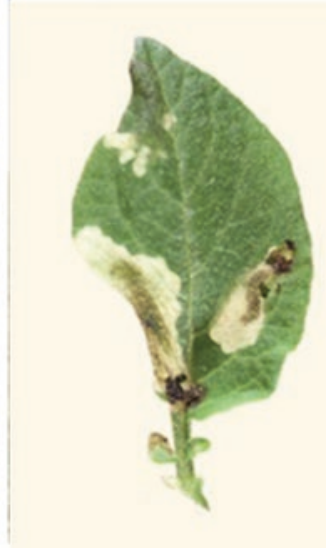

C

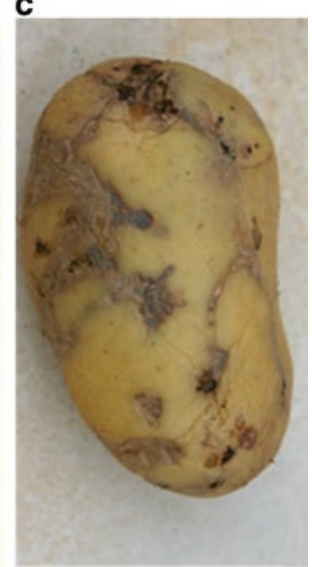

Fig. 8.19 Adult of Tuta absoluta (a), larvae infestation on potato leaf (b), and tuber (c). (Photo credits: CIP) 
the larva develops, causing deformation or rot of the affected leaves. The larvae can migrate to another part of the plant, especially when they reach their maximum development or when the affected foliage withers and dries (CIP 1996; Notz 1992; EPPO 2005b).

Impacts on production losses T. absoluta is a major pest of tomato (Lycopersicum esculentum), but it also attacks potato. Larval feeding causes desiccation of damaged leaves and shoots, resulting in low tuber production. Larval damage is generally accentuated in young plants in the tuberization phase. Possibilities of T. absoluta infestation of potato tubers are very low and restricted to very high field infestation rates during the last stage of the crop (CIP 1996; CABI 2017k; OIRSA 2015b; SENASICA 2016).

\section{Methods of prevention and control}

Monitoring with pheromone traps. Pheromone traps can be used both for early detection and for monitoring the flight activity of the pest. They can also help to reduce the population when used for mass trapping, in which case a higher number of traps need to be deployed. For monitoring purposes, one trap should be placed per hectare (Niederwieser 2017; OIRSA 2015b).

Cultural practices. Good agricultural practices for the control of T. absoluta include crop rotation with non-solanaceous crops (preferably cruciferous crops), ploughing, adequate irrigation and fertilization, removal of infested plants, and complete removal of post-harvest plant debris.

Biological control. Nesidiocoris tenuis Reuter is an efficient predator of eggs and small larvae of the tomato tuber moth. Egg parasitoids of the family Trichogrammatidae are the natural enemies most used worldwide in biological control programs against Lepidoptera, through inoculative and inundative releases. Releases of Trichogramma pretiosum Riley reduced the population of T. absoluta to a maximum of $49 \%$. Therefore, combinations with the application of a bioinsecticide based on Bacillus thuringiensis subsp. kurstaki have been recommended (Niederwieser 2017).

Botanicals/Biopesticides. Neem oil (Azadirachtin) acts as a contact and systemic insecticide and has been shown to be effective against low infestations of T. absoluta and for controlling first and second instar larva. The use of Bacillus thuringensis is recommended at low-medium infestation levels in combination with Azadirachtin (SENASICA 2016).

Chemical control. Several insecticides have been effectively used against T. absoluta in potato; however, this pest is known to develop resistance against effective insecticides.

\subsubsection{Potato Leafhoppers}

\section{Empoasca fabae (Harris 1841) (Hemiptera: Cicadellidae)}

Distribution The leafhopper Empoasca fabae is widely distributed (Fig. 8.20). 

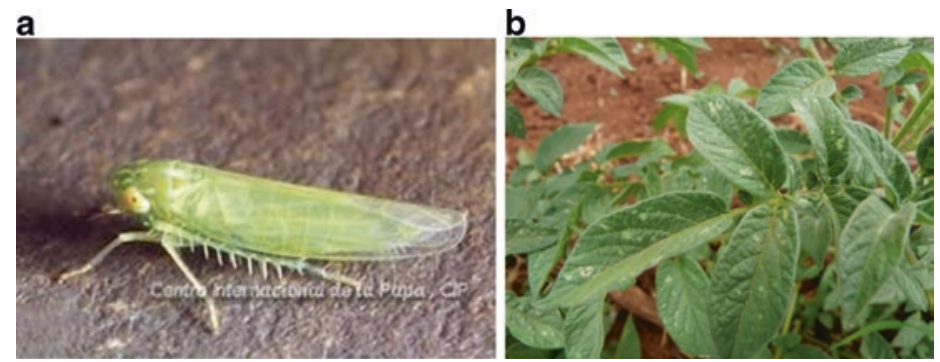

Fig. 8.20 Empoasca fabae adult (a); and potato leave damage (b). (Courtesy by CIP)

Host range E. fabae is a polyphagous pest. Its main hosts are potato, alfalfa, eggplant, bean, celery, cucumber, cucurbits, groundnut (Arachis hypogaea L.), melon, rhubarb (Rheum rhabarbarum L.), strawberry, sweet potato, and tomato.

Symptoms of infestation The potato leafhopper $E$. fabae is a sucking insect that extracts sap directly from the vascular system of the leaflets, petioles and sometimes the stems. The attack on potato crops is sporadic and is favored by humid conditions. Insects live in the abaxial (lower) part of the leaflets. They inject toxic saliva while feeding, causing leaf necrosis and interfering with plant growth. Under severe attack, the attacked plants die prematurely. Leafhopper can transmit some viruses, although their occurrence is rare (CIP 1996; Cook et al. 2004; Larrain et al. 2003).

Impacts on production losses The complex of symptoms caused by the leafhopper leads to reduced growth and reproduction of plants. Depending on the stage of plant development, in heavily infested fields up to $75 \%$ the yield can be lost (Backus et al. 2005; Cook et al. 2004; Medeiros et al. 2004). E. fabae has become a major pest with the introduction of modern synthetic insecticides. In Minnesota, USA, annual losses to potato were estimated at \$US 7 million (Noetzel et al. 1985). The relationship between yield loss and leafhopper numbers have been determined to be directly linear (Radcliffe and Johnson 1994). In south western Ontario, Canada, average losses of up to $85 \%$ for potatoes have been recorded (Tolman et al. 1986). E. fabae is also a serious pest of potato in some parts of India with severe hopper burn especially of early planted crops (Verma et al. 1994).

\section{Methods of prevention and control}

Most of the potato leafhopper management in potato and other crops is based on monitoring, cultural control, and the use of insecticides.

Monitoring. The presence of the leafhopper can be determined rapidly using entomological nets or yellow sticky traps located at the edges of the crop. Nymphs are best monitored by examining the leaves, especially the underside. Monitoring middle part of a plant gives a more precise estimate of the population of leafhopper nymphs than monitoring basal and apical parts. The economic threshold in potato is 10 or more nymphs per 100 leaves, or $10 \%$ of the leaves infested with nymphs (CIP 1996; Cook et al. 2004). 
Cultural practices. Infestation of potato fields may be prevented by avoiding proximity to crops such as beans that host high leafhopper populations. Also, elimination of crop residues and appropriate irrigation help reduce populations of this pest (Larrain et al. 2003).

Natural control. Although the leafhopper has several natural enemies, such as predators and parasites, they play a very minor role in potato leafhopper control (CIP 1996; Cook et al. 2004; Larrain et al. 2003).

Plant resistance. Resistant or tolerant varieties should be considered in affected regions, but if leafhopper populations increase, systemic insecticides may become necessary (Backus et al. 2005).

Chemical control. Applications must be made only if populations reach economic thresholds.

\subsubsection{Leaf Beetles}

\section{Diabrotica viridula Fabricius, D. speciosa Erichson(Coleoptera: Chrysomelidae)}

Distribution Central America (Costa Rica and Panama) and South America (Argentina, Bolivia, Brasil, Columbia, Ecuador, French Guyana, Paraguay, Peru, Uruguay, and Venezuela (Fig. 8.21).

Host range South American Diabrotica species are presented in at least 116 species in 24 families. Diabrotica speciosa larvae developed well on maize, peanut (Arachis hypogaea L.), and soybean roots, and not so well on pumpkin (Cucurbita maxima Duchesne and Cucurbita andreana Naudin), beans (Phaseolus spp.), and potato roots. Diabrotica viridula, preferred maize as adult and larval food, and for oviposition (Cabrera 2003).

Symptoms of infestation Feeding on leaflets by adults interferes with photosynthesis and, therefore, reduces production of tubers. Larvae damage stolons and form galleries in tubers (Cabrera 2003; Lara et al. 2004).

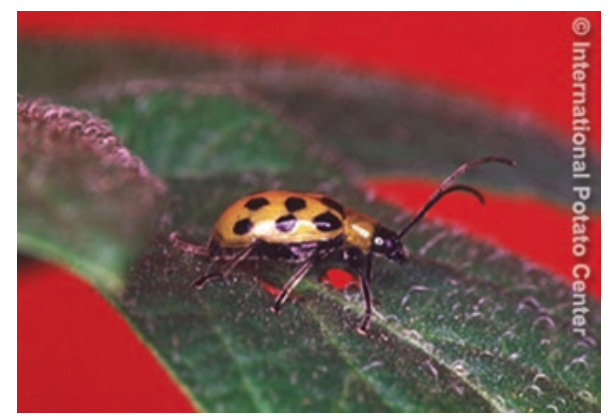

Fig. 8.21 Adult of Diabrotica speciosa. (Photo credits: CIP) 
Impacts on production losses In some areas, the most important economic damage to potato is caused by the subterranean larvae gnawing the surface of tubers, which lose quality and become susceptible to soil pathogens (CIP 1996). Eggs and larvae do not develop under dry conditions, so damage is most severe during wet seasons.

\section{Methods of prevention and control}

Cultural practices. Deep tillage leads to exposing of larvae and pupae to the action of predators and adverse environmental factors. Weeds that serve as alternating hosts should be eliminated (CIP 1996; Sanchez and Vergara 2002).

Chemical control. In cases of heavy infestation, especially when potato plants are small, insecticide applications are recommended against adult beetles (CIP 1996; Sanchez and Vergara 2002).

\subsection{Concluding Remarks}

Since potato is a major crop for humankind, it has a global distribution and it is attacked by a myriad pests which can substantially reduce its productivity and its quality. The increasing awareness about the nutritional, agronomic, and cash creating advantages potato provides is likely to further increase its status as a global crop, particularly in developing subtropical and tropical countries. The development, adaptation and use of integrated pest management will be an important area of future research crucial for a sustainable and more resilient and economic profitable potato production in all potato growing regions worldwide. Emphasis should be given to develop and use biological approaches in pest management. This will reduce the dependence on insecticides as well as will reduce the risk that insect populations develop resistance against insecticides.

Previous work has clearly shown that many insect pests of potato will respond to climate change by expanding their geographical range of distribution and increasing population densities will lead to greater crop and post-harvest losses, particularly in subtropical and tropical regions. Modeling of the response of potato pest populations to global warming will help to predict potential changes in pest distribution and severity in order to support potato growers in the adaptation of their pest management strategies.

\section{References}

Alcázar J, Cisneros F (1999) Taxonomy and bionomics of the Andean potato weevil complex: Premnotrypes spp. and related genera. In: Arthur C, Ferguson P, Smith B (eds) Impact on a changing world: program report 1997-98. International Potato Center, Lima, pp 141-151. http://www.cipotato.org/market/PgmRprts/pr97-98/17weevil. Accessed 11 Jun 2018

Alcázar J, Kroschel J (2008) Andean potato weevil. In: Wale SJ, Platt HW, Cattlin ND (eds) Diseases, pests and disorders of potatoes: a color handbook. Academic Press, Boston, pp 129-131 
Alyokhin A (2009) Colorado potato beetle management on potatoes: current challenges and future prospects. In: Tennant P, Benkeblia N (eds) Potato II. Fruit, vegetable and cereal science and biotechnology, vol 3 (Special Issue 1), pp 10-19

Alyokhin A, Chen YH (2017) Adaptation to toxic hosts as a factor in the evolution of insecticide resistance. Curr Opinion Insect Sci 21(1):33-38

Alyokhin A, Chen YH, Udalov M, Benkovskaya G, Lindström L (2013) Evolutionary considerations in potato pest management. In: Giordanengo P, Vincent C, Alyokhin A (eds) Insect pests of potato: global perspectives on biology and management. Academic Press, Oxford, pp 543-571

Alyokhin A, Mota-Sanchez D, Baker M, Snyder WE, Menasha S, Whalon M, Dively G, Moarsi WF (2015) Red Queen on a potato field: IPM vs. chemical dependency in Colorado potato beetle control. Pest Manage Sci 71(3):343-356

Anderson PK et al (2005) Whitefly and whitefly-borne viruses in the tropics: building a knowledge base for global action. International Center for Tropical Agriculture (CIAT), Cali, Colombia, p 351

Arthropod Pesticide Resistance Database (2018). https://www.pesticideresistance.org. Accessed 3 Jul 2018

Backus EA, Serrano MS, Ranger CM (2005) Mechanisms of hopperburn: an overview of insect taxonomy, behavior, and physiology. Annu Rev Entomol 50:125-151

Baker WA, Bradley WG, Clark CA (1949) Biological control of the European corn borer in the United States. Tech Bull U S Dep Agri 983:1-185

Bentley WJ, Rice RE (2015) UC IPM pest management guidelines: Nectarine UC IPM Program, Kearney Agricultural Center, Parlier, USA. http://ipm.ucanr.edu/PMG/r540300411.html. Accessed 2 Nov 2018

BioNET-EAFRINET (2011) White grubs. Keys and fact sheets. http://keys.lucidcentral.org

Blackman RL, Eastop VF (2000) Aphids on the world's crops: an identification and information guide, 2nd edn. Wiley, New York

Butler CD, Trumble JT (2012) The potato psyllid, Bactericera cockerelli (Sulc) (Hemiptera: Triozidae): life history, relationship to plant diseases, and management strategies. Terr Arthropod Rev 5:87-111. https://doi.org/10.1163/187498312X634266

CABI (2012) Liriomyza huidobrensis (Blanchard). Invasive species compendium: datasheets, maps, images, abstracts and full text on invasive species of the world. http://www.cabi.org/isc/ datasheet/30956. Accessed 2 Feb 2018

CABI (2016) Bactericera cockerelli (tomato/potato psyllid). http://www.cabi.org/isc/datasheet/45643. Accessed 20 Feb 2018

CABI (2017a) Leptinotarsa decemlineata (Colorado potato beetle) data sheet. In: Invasive species compendium. CAB International, Wallingford, UK. http://www.cabi.org/isc/datasheet/30380. Accessed 25 Feb 2018

CABI (2017b) Ostrinia nubilalis (European maize borer). In: Invasive species compendium. CAB International, Wallingford, UK. http://eol.org/pages/464566/details. Accessed 4 Feb 2018

CABI (2017c) Myzus persicae (green peach aphid). In: Invasive species compendium. CAB International, Wallingford, UK. http://www.cabi.org/isc/datasheet/35642. Accessed $20 \mathrm{Feb} 2018$

CABI (2017d) Macrosiphum euphorbiae (potato aphid). In: Invasive species compendium. CAB International, Wallingford, UK. http://www.cabi.org/isc/datasheet/32154. Accessed 5 Feb 2018

CABI (2017e) Bemisia tabaci [original text by Andrew Cuthbertson]. In: Invasive species compendium. CAB International, Wallingford, UK. http://www.cabi.org/isc/datasheet/8927. Accessed 6 Feb 2018

CABI (2017f) Trialeurodes vaporariorum. In: Invasive species compendium. CAB International, Wallingford, UK. http://www.cabi.org/isc/datasheet/54660. Accessed 7 Feb 2018

CABI (2017g) Tetranychus urticae (two-spotted spider mite) data sheet. In: Invasive species compendium. CAB International, Wallingford, UK. http://www.cabi.org/isc/datasheet/53366. Accessed 8 Feb 2018

CABI (2017h) Polyphagotarsonemus latus data sheet. In: Invasive species compendium. CAB International, Wallingford, UK. http://www.cabi.org/isc/datasheet/26876. Accessed 9 Feb 2018 
CABI (2017i) Frankliniella occidentalis (western flower thrips). In: Invasive species compendium. CAB International, Wallingford, UK. https://www.cabi.org/ISC/datasheet/24426. Accessed 5 Feb 2018

CABI (2017j) Trips tabaci (onion thrips). In: Invasive species compendium. CAB International, Wallingford, UK. http://www.cabi.org/isc/datasheet/53746. Accessed 11 Feb 2018

CABI (2017k) Tuta absoluta datasheet. In: Invasive species compendium. CAB International, Wallingford, UK. http://www.cabi.org/isc/datasheet/49260. Accessed 12 Feb 2018

CABI (2018a) Agrotis ipsilon (black cutworm) datasheet. In: Invasive species compendium. Wallingford, UK: CAB International. https://www.cabi.org/isc/datasheet/3801. Accessed 10 Dec 2018

CABI (2018b) Spodoptera frugiperda (fall armyworm) datasheet. In: Invasive species compendium. CAB International, Wallingford, UK. https://www.cabi.org/isc/datasheet/29810. Accessed 10 Dec 2018

CABI (2018c) Spodoptera eridania (southern armyworm). In: Invasive species compendium. CAB International, Wallingford, UK. https://www.cabi.org/ISC/datasheet/44518. Accessed 10 Dec 2018

CABI (2018d) Mamestra configurata (bertha armyworm). In: Invasive species compendium. CAB International, Wallingford, UK. https://www.cabi.org/isc/datasheet/8492. Accessed 10 Dec 2018

Cabrera G (2003) Host range and reproductive traits of Diabrotica speciosa (Germar) and Diabrotica viridula (F.) (Coleoptera: Chrysomelidae), two species of South American pest rootworms, with notes on other species of Diabroticina. Environ Entomol 32(2):276-285. https://doi.org/10.1603/0046-225X-32.2.276

Canedo, V, Carhuapoma P, López E, Kroschel J (2016a) Copidosoma koehleri (Blanchard 1940). In: Kroschel J, Mujica N, Carhuapoma P, Sporleder M (eds) Pest distribution and risk atlas for Africa. Potential global and regional distribution and abundance of agricultural and horticultural pests and associated biocontrol agents under current and future climates. International Potato Center (CIP), Lima (Peru), pp. 208-219. https://doi.org/10.4160/9789290604761-16. ISBN 978-92-9060-476-1

Canedo V, Carhuapoma P, Dávila W, Kroschel J (2016b) Apanteles subandinus (Blanchard 1947). In: Kroschel J, Mujica N, Carhuapoma P, Sporleder M (eds) Pest distribution and risk atlas for Africa. Potential global and regional distribution and abundance of agricultural and horticultural pests and associated biocontrol agents under current and future climates. International Potato Center (CIP), Lima (Peru), pp 220-231. https://doi.org/10.4160/9789290604761-17

Canedo V, Carhuapoma P, Bartra C, Kroschel J (2016c) Orgilus lepidus (Muesebeck 1967). In: Kroschel J, Mujica N, Carhuapoma P, Sporleder M (eds) Pest distribution and risk atlas for Africa. Potential global and regional distribution and abundance of agricultural and horticultural pests and associated biocontrol agents under current and future climates. International Potato Center (CIP), Lima (Peru), pp 232-244. https://doi.org/10.4160/9789290604761-18

Capinera JL (2001) Handbook of vegetable pests. Academic Press, San Diego, p 729

Castillo JR (2010) Prodiplosis longifila in Peru. https://conference.ifas.ufl.edu/TSTAR/presentations/Tuesday/pm/4\%2020pm\%20J\%20Castillo.pdf. Accessed 20 Feb 2018

CIP (1996) Major potato diseases, insects, and nematodes. International Potato Center, Lima, Peru, p 61

Cisneros F, Mujica N (1999a) Impacto del cambio climático en la agricultura: Efectos del fenómeno El Nino en los cultivos de la costa central. Consejo Nacional del Ambiente (CONAM), Lima (Peru), pp 115-133

Cisneros F, Mujica N (1999b) The leafminer fly in potato: plant reaction and natural enemies as natural mortality factors. International Potato Center, Lima, Peru, pp 129-140

Cisneros F, Mujica N (1999c) Biological and selective control of the sweet potato whitefly, Bemisia tabaci (Gennadius) (Hom.: Aleyrodidae). International Potato Center, Lima, Peru. Program Report 1997-98, pp 255-264 
Cook KA, Ratcliffe ST, Gray ME, Steffey KL (2004) Potato leafhopper (Empoasca fabae (Harris)). Insect Fact Sheet, University of Illinois, Department of Crop Sciences. https://ipm.illinois.edu/ fieldcrops/insects/potato_leafhopper.pdf

Dillon ME, Wang G, Huey RB (2010) Global metabolic impacts of recent climate warming. Nature 467:704-706

EPPO (2005a) Tecia solanivora. EPPO Bull 35:399-401

EPPO (2005b) Tuta absoluta. Data sheets on quarantine pests. Bull OEPP/EPPO Bull 35:434-435

EPPO (2014) PQR database. European and Mediterranean Plant Protection Organization, Paris, France. http://www.eppo.int/DATABASES/pqr/pqr.htm

EPPO (2015) Prodiplosis longifila (Diptera: Cecidomyiidae). In: EPPO technical document No. 1068, EPPO study on pest risks associated with the import of tomato fruit. EPPO Paris, pp 133-134. https://www.eppo.int/QUARANTINE/DT_1068_Tomato_study_MAIN_TEXT_ and_ANNEXES_2015-01-26.pdf

European Parliament and the Council of the European Union (2009) Directive2009/128/EC of the European Parliament and of the Council of 21 October 2009 establishing a framework for Community action to achieve the sustainable use of pesticides. Official Journal of the European Union, L309/71. First published 2009. http://eur-lex.europa.eu/legal-content/EN/ALL/?uri=ce lex\%3A32009L0128

Eyre D, Giltrap N (2013) Epitrix flea beetles: new threats to potato production in Europe. Pest Manage Sci 69(1):3-6

FAO (2018). http://www.fao.org/agriculture/crops/core-themes/theme/pests/ipm

Ferro DN (2000) Success and failure of Bt products: Colorado potato beetle-a case study. In: Kennedy GG, Sutton TB (eds) Emerging technologies for integrated pest management: concepts, research, and implementation. APS Press, St. Paul, pp 177-189

Forgash AG (1985) Insecticide resistance in the Colorado potato beetle. In: Ferro DN, Voss RH (eds) Proceedings, Symposium on the Colorado potato beetle. XVIIth International Congress of Entomology. Res. Bull. 704, Mass Agric Exp Stn Circ 347, pp 33-52

Franco-Lara L, Rodríguez D, Guzmán-Barney M (2013) Prevalence of potato yellow vein virus (PYVV) in Solanum tuberosum group Phureja fields in three states of Colombia. Am J Potato Res 90(4):324-330

Furth DG, Savini V, Chaboo CS (2015) Beetles (Coleoptera) of Peru: a survey of the families. Chrysomelidae: Alticinae (flea beetles). J Kans Entomol Soc 88(3):368-374

Gagné RJ (1986) Revision of Prodiplosis (Diptera: Cecidomyiidae) with descriptions of three new species. Ann Entomol Soc Am 79(1):235-245

Gamarra H, Mujica N, Carhuapoma P, Kreuze J, Kroschel J (2016a) Sweetpotato white fly, Bemisia tabaci (Gennadius 1989) (Biotype B). In: Kroschel J, Mujica N, Carhuapoma P, Sporleder M (eds) Pest distribution and risk atlas for Africa-potential global and regional distribution and abundance of agricultural and horticultural pests and associated biocontrol agents under current and future climates. International Potato Center (CIP), Lima, Peru, pp 85-99. https://doi. org/10.4160/9789290604761 (online publication: http://cipotato.org/riskatlasforafrica/)

Gamarra H, Carhuapoma P, Mujica N, Kreuze J, Kroschel J (2016b) Greenhouse whitefly, Trialeurodes vaporariorum (Westwood 1956). In: Kroschel J, Mujica N, Carhuapoma P, Sporleder M (eds) Pest distribution and risk atlas for Africa-potential global and regional distribution and abundance of agricultural and horticultural pests and associated biocontrol agents under current and future climates. International Potato Center (CIP), Lima, Peru, pp 154-168. https://doi.org/10.4160/9789290604761 (online publication: http://cipotato.org/ riskatlasforafrica/)

Garzón TJA (2002) Asociación de Paratrioza cockerelli Sulc. con enfermedades en papa (Solanum tuberosum) y tomate (Lycopersicum lycopersicum Mil. Ex. Fawnl) en México. In: Memoria del Taller sobre 11 Paratrioza cockerelli (Sulc.) como plaga y vector de fitoplasmas en hortalizas. Culiacán, Sinaloa, México, pp 79-87

Ghosh SK, Chakraborty G (2012) Integrated field management of Henosepilachna vigintioctopunctata (Fabr.) on potato using botanical and microbial pesticides. J Biopest 5(Suppl):151-154 
Goftishu M, Dejene M, Kassaye A, Belay T (2016) Red Spider Mite, Tetranychus urticae Koch (Arachnida: Acari-Tetranychidae): a threatening pest to potato (Solanum tuberosum). Pest Manage J Ethiopia 19:53-59

Gonzales-Bustamante L (1996) Prodiplosis longifila infestando vainas del pallar en Lima. Rev Peru Entomol 39:118

Gupta S, Gavkare O (2014) White grub, Brahmina coriacea, a potential threat to potato. J Ind Pollut Control 30(2):357-359

Hazzard R (2008) New England vegetable management guide. New England extension systems, University of Massachusetts, Amherst, MA. https://ag.umass.edu/vegetable/fact-sheets/twospotted-spider-mite. Accessed 2 Nov 2018

Hazzard R (2013) New England vegetable management guide. New England extension systems, University of Massachusetts, Amherst, MA. https://ag.umass.edu/vegetable/fact-sheets/twospotted-spider-mite. Accessed 23 Sep 2019

Henne DC, Paetzold L, Workneh F, Rush CM (2010) Evaluation of potato psyllid cold tolerance, overwintering survival, sticky trap sampling, and effects of liberibacter on potato psyllid alternate host plants. In: Workneh F, Rush CM (eds), Proceedings of the 10th Annual Zebra Chip Reporting Session, pp. 149-153. Dallas, TX (November 7-10, 2010)

Hernandez LM (2014) Caracterización del daño y distribución geográfica de Cecidomyiidae (Diptera) y sus parasitoides asociados a Solanáceas y limón Tahití en Colombia. Tesis de Maestría en Ciencias Agrarias. Línea Protección de Cultivos. Universidad Nacional de Colombia. Palmira, $93 \mathrm{p}$

Hernandez LM, Guzman YC, Martínez-Arias A, Manzano MR, Selvaraj JJ (2015) The bud midge Prodiplosis longifila: damage characteristics, potential distribution and presence on a new crop host in Colombia. SpringerPlus 4:205. https://doi.org/10.1186/s40064-015-0987-6

Horn P, Page J (2008) Integrated pest management dealing with potato tuber moth and all other pests in Australian potato crops. In: Kroschel J, Lacey L (eds) Integrated pest management for the potato tuber moth, Phthorimaea operculella (Zeller) — a potato pest of global importance. Tropical Agriculture 20, Advances in Crop Research 10. Margraf Publishers, Weikersheim, Germany, pp 111-117

Jackson G (2016) Potato ladybird beetle (255). Pacific pests and pathogens fact sheet. PestNet, Queensland, Australia

Jacques RL, Fasulo TR (2015) Colorado potato beetle Leptinotarsa decemlineata. DPI Entomology Circular 271. Florida Department of Agriculture and Consumer Services, Division of Plant Industry and University of Florida. http://entnemdept.ufl.edu/creatures/veg/leaf/potato_beetles.htm

Jeger M, Bragard C, Caffier D, Candresse T, Chatzivassiliou E, Dehnen-Schmutz K, Gilioli G, Gregoire J-C, Jaques Miret JA, Navajas Navarro M, Niere B, Parnell S, Potting R, Rafoss T, Rossi V, Urek G, Van Bruggen A, Van der Werf W, West J, Winter S, Gardi C, Bergeretti F, MacLeod A (2018) Scientific opinion on the pest categorisation of Tecia solanivora. EFSA J 16(1):5102,. pp 25. https://doi.org/10.2903/j.efsa.2018.5102

Jeyasankar A, Premalatha S, Elumalai K (2014) Antifeedant and insecticidal activities of selected plant extracts against Epilachna beetle, Henosepilachna vigintioctopunctata (Coleoptera: Coccinellidae). Adv Entomol 2(1):14-19

Kabaluk JT, Goettel M, Erlandson M, Ericsson J, Duke G, Vernon R (2005) Metarhizium anisopliae as a biological control for wireworms and a report of some other naturally-occurring parasites. IOBC/WPRS Bull 28(2):109-115

Katakura H (1980) Classification and evolution of the phytophagous ladybirds belonging to Henosepilachna vigintioctomaculata complex (Coleoptera, Coccinellidae). PhD Dissertation, Hokkaido University, Japan

Kaya H, Alcazar J, Parsa S, Kroschel J (2009) Microbial control of the Andean potato weevil complex. Fruit Veg Cereal Sci Biotechnol 3(Special Issue 1):39-45

Keller S (2003) Integrated pest management of the potato tuber moth in cropping systems of different agroecological zones. In: Kroschel J (ed) Tropical Agriculture 11, Advances in Crop Research 1. Margraf Publishers, Weikersheim, Germany, p 153 
Kennedy GG (1983) Effects of European corn borer (Lepidoptera: Pyralidae) damage on yields of spring-grown potatoes. J Econ Entomol 76(2):316-322

Kim JJ, Jeong G, Han JH, Lee S (2013) Biological control of aphid using fungal culture and culture filtrates of Beauveria bassiana. Mycobiology 41(4):221-224. https://doi.org/10.5941/ MYCO.2013.41.4.221

Kogan M (1998) Integrated pest management: historical perspectives and contemporary developments. Annu Rev Entomol 43:243-270

Kroschel J (1994) Population dynamics of the potato tuber moth, Phthorimaea operculella, in Yemen and its effects on yield. In: Proceedings of the Brighton crop protection conference, pests and diseases, vol I. Brighton, UK, pp 241-246

Kroschel J (1995) Integrated Pest Management in potato production in the Republic of Yemen with special reference to the integrated biological control of the potato tuber moth (Phthorimaea operculella Zeller). Tropical Agriculture 8. Margraf Verlag, Weikersheim, Germany, p 227

Kroschel J, Koch W (1996) Studies on the use of chemicals, botanicals and Bacillus thuringiensis in the management of the potato tuber moth in potato stores. Crop Prot 15(2):197-203

Kroschel J, Schaub B (2013) Biology and ecology of potato tuber moths as major pests of potato. In: Giordanengo P, Vincent C, Alyokhin A (eds) Insect pests of potato: global perspectives on biology and management. Academic Press, Oxford, pp 165-192

Kroschel J, Sporleder M (2006) Ecological approaches to integrated pest management of the potato tuber moth, Phthorimaea operculella Zeller (Lepidoptera, Gelechidae). In: Proceedings of the 45th Annual Washington State Potato Conference, February 7-9, 2006, Moses Lake, Washington, pp 85-94

Kroschel J, Zegarra O (2010) Attract-and-kill: a new strategy for the management of the potato tuber moths Phthorimaea operculella (Zeller) and Symmetrischema tangolias (Gyen) in potato-Laboratory experiments towards optimizing pheromone and insecticide concentration. Pest Manage Sci 66:490-496

Kroschel J, Zegarra O (2013) Attract-and-kill as a new strategy for the management of the potato tuber moths Phthorimaea operculella (Zeller) and Symmetrischema tangolias (Gyen) in potato: evaluation of its efficacy under potato field and storage conditions. Pest Manage Sci 69(11):1205-1215

Kroschel J, Kaack HJ, Fritsch E, Huber J (1996) Biological control of the potato tuber moth (Phthorimaea operculella Zeller) in the Republic of Yemen using granulosis virus: Propagation and efficacy of the virus in field trials. Biocontrol Sci Technol 6:217-226

Kroschel J, Alcazar J, Pomar P (2009) Potential of plastic barriers to control Andean potato weevil Premnotrypes suturicallus Kuschel. Crop Prot 28:466-476

Kroschel J, Cañedo V, Alcázar J (2011) Manual de capacitación para extensionistas: Manejo de plagas de la papa en la región Andina del Perú. International Potato Center, Lima, Peru, p 88

Kroschel J, Mujica N, Alcazar J, Canedo V, Zegarra O (2012) Developing integrated pest management for potato: experiences and lessons from two distinct potato production systems of Peru. In: He Z, Larkin RP, Honeycutt CW (eds) Sustainable potato production: global case studies. Springer, UK, pp 419-450

Kroschel J, Sporleder M, Tonnang HEZ, Juarez H, Carhuapoma P, Gonzales JC, Simon R (2013) Predicting climate change caused changes in global temperature on potato tuber moth Phthorimaea operculella (Zeller) distribution and abundance using phenology modeling and GIS mapping. Agric For Meteorol 170:228-241

Kroschel J, Mujica N, Carhuapoma P, Sporleder M (2016a) Pest Distribution and Risk Atlas for Africa-potential global and regional distribution and abundance of agricultural and horticultural pests and associated biocontrol agents under current and future climates. International Potato Center (CIP), Lima, Peru, p 650. https://doi.org/10.4160/9789290604761. (online publication: http://cipotato.org/riskatlasforafrica/)

Kroschel J, Sporleder M, Carhuapoma P (2016b) Potato tuber moth, Phthorimaea operculella (Zeller). In: Kroschel J, Mujica N, Carhuapoma P, Sporleder M (eds) Pest distribution and risk atlas for Africa - potential global and regional distribution and abundance of agricultural and horticultural pests and associated biocontrol agents under current and future climates. International Potato Center, Lima, Peru, pp 7-23. https://doi.org/10.4160/9789290604761. (online publication: http://cipotato.org/riskatlasforafrica/) 
Lacey L, Kroschel J (2009) Microbial control of the potato tuber moth (Lepidoptera: Gelechiidae). Fruit, Veg Cereal Sci Biotech 3:46-54

Lacey LA, Liu T-X, Buchman JL, Munyaneza JE, Goolsby JA, Horton DR (2011) Entomopathogenic fungi (Hypocreales) for control of potato psyllid, Bactericera cockerelli (Šulc) (Hemiptera: Triozidae) in an area endemic for zebra chip disease of potato. Biol Control 56 (3):271-278

Landis BJ, Davis EW (1947) Two-spotted spider mite damage to potatoes. J Econ Entomol 40(4):565-565

Lara FM, Scaranello AL, Baldin ELL, Boiça-Junior L, Lourenção AL (2004) Resistência de genótipos de batata a larvas e adultos de Diabrotica speciosa. Hortic Bras 22(4):761-765

Larrain P, Kalazich J, Carrillo R, Cisternas E (2003) Plagas de la papa y su manejo. Colección libros INIA- $\mathrm{N}^{\circ}$ 9. Instituto de Investigaciones Agropecuarias, Ministerio de Agricultura. La Serena, Chile

Laznik Ž, Tóth T, Lakatos T, Vidrih M, Trdan S (2010) Control of the Colorado potato beetle (Leptinotarsa decemlineata [Say]) on potato under field conditions: a comparison of the efficacy of foliar application of two strains of Steinernema feltiae (Filipjev) and spraying with thiametoxam. J Plant Dis Prot 117(3):129-135

Learmonth S (2017) Thrips: potato pest in Indonesia and Western Australia. Department of Primary Industries and Regional Development. https://www.agric.wa.gov.au/potatoes/ thrips-potato-pest-indonesia-and-western-australia

Li WD, Chen SX, Qin JG (2003) Identification of sympatric Asian and European corn borers. Entomol Knowl 40(1):31-35

Malumphy C, Everatt M, Eyre D, Giltrap N (2016) Potato flea beetle, Epitrix species. Plant pest factsheet. Department for Environment Food \& Rural Affairs, United Kingdom, pp 1-6

Mamani D, Sporleder M, Kroschel J (2011) Efecto de materiales inertes de fórmulas bioinsecticidas en la protección de tubérculos almacenados contra las polillas de papa (Effect of inert materials of bioinsecticides formula to protect stored tubers of potato against the potato moths). Rev Peru Entomol 46:43-49

Martin NA (2016) Tomato potato psyllid-Bactericera cockerelli. Interesting insects and other invertebrates. New Zealand Arthropod Factsheet Series Number 60. http://nzacfactsheets.landcareresearch.co.nz/Index.html

Mauchline N, Stannard K (2013) Evaluation of selected entomopathogenic fungi and bioinsecticides against Bactericera cockerelli (Hemiptera). NZ Plant Prot 66:324-332. https://doi. org/10.30843/nzpp.2013.66.5707

Medeiros A, Tingey W, De Jong W (2004) Mechanisms of resistance to potato leafhopper, Empoasca fabae (Harris). Am J Potato Res 81(6):431-441

Misra SS (1995) White grub, Holotrichia (Lachnosterna) coracea (Hope)-A key pest of potatoes in Himachal Pradesh (India). J Entomol Res 9(2):181-182

Misra SS, Chandel RS (2003) Potato white grubs in India. Tech Bull 60

Muchemi SK, Ngichop FC, Fiaboe KKM (2014) Report of the establishmnet of the released hymenoptera Phaedrotoma scabriventris Nixon (Braconidae), Halticpotera arduine (Walker) (Pteromalidae) and Chrysocharis flacilla (Walker) (Eulophidae) in vegetables production systems of Kenya. Submitted to Kenyan Plant Health Inspectorate Service (KEPHIS). International Centre of Insect Physiology and Ecology (icipe), 13 pp.

Mujica N (1998) Uso de trampas amarillas en el control de adultos de mosca minadora y mosca blanca. International Potato Center, Lima, Peru. Hoja divulgativa $\mathrm{N}^{\circ} 1$

Mujica N (2016) Ecological approaches to manage the leafminer fly Liriomyza huidobrensis (Blanchard) in potato-based agroecosystems of Peru. In: Kroschel J (ed) Tropical agriculture 21-Advances in crop research, vol 11. Margraf Verlag, Weikersheim, Germany, p 255

Mujica N, Kroschel J (2013) Pest intensity-crop loss relationships for the leafminer fly Liriomyza huidobrensis (Blanchard) in different potato (Solanum tuberosum L.) varieties. Crop Prot 47:6-16

Mujica N, Kroschel J (2018) Ecological, economic and environmental assessments of Integrated Pest Management technologies: case study for potato lowland systems in the Cañete valley. Food Energy Secur 8:e0153. https://doi.org/10.1002/fes3.153 
Mujica N, Alcázar J, Kroschel J (2013) Interacción del nematode entomopatogénico Heterorhabditis indica (RHABDITIDA: HETERORHABDITIDAE) y el ectoparasitoide Diglyphus begini (HYMENOPTERA: EULOPHIDAE) en el control de la mosca minadora Liriomyza huidobrensis (DIPTERA: AGROMYZIDAE). LV Convencion Nacional de Entomologia November 4-7, 2013, Lima-Peru

Mujica N, Carhuapoma P, Kroschel J (2016) Serpentine leafminer fly, Liriomyza huidobrensis (Blanchard 1926). In: Kroschel J, Mujica N, Carhuapoma P, Sporleder M (eds) Pest distribution and risk atlas for Africa-potential global and regional distribution and abundance of agricultural and horticultural pests and associated biocontrol agents under current and future climates. International Potato Center (CIP), Lima, Peru, pp 114-125. https://doi. org/10.4160/9789290604761 (online publication: http://cipotato.org/riskatlasforafrica/)

Mujica N, Sporleder M, Carhuapoma P, Kroschel J (2017) A temperature-dependent phenology model for the leafminer fly Liriomyza huidobrensis (Blanchard) (Diptera: Agromyzidae). J Econ Entomol 110(3):1333-1344

Mujica N, Fonseca C, Suarez F, Fabian F, Marchena M, Cisneros F (2000) Reducción del uso de insecticidas en el control de la mosca minadora, Liriomyza huidobrensis Blanchard, por medio del uso de técnicas etológicas. In: Arning G, A Lizárraga (eds.), Control Etológico. Uso de feromonas, trampas de colores y luz para el control de plagas en la agricultura sostenible. Lima, Perú

Munyaneza JE, Crosslin JM, Upton JE (2007) Association of Bactericera cockerelli (Homoptera: Psyllidae) with "zebra chip", a new potato disease in southwestern United State and Mexico. J Econ Entomol 100(3):656-663

Munyaneza JE, Sengoda VG, Crosslin JM, De la Rosa-Lozano G, Sánchez A (2009) First report of "Candidatus Liberibacter psyllaurous" in potato tubers with zebra chip disease in Mexico. Plant Dis 93(5):552

Nault BA, Kennedy GG (1996) Timing insecticide applications for managing European corn borer (Lepidoptera: Pyralidae) infestations in potato. Crop Prot 15(5):465-471

Naz F, Inayatullah M, Rafi MA, Ashfaque M, Ali A (2012) Henosepilachna vigintioctopunctata (Fab.) (Epilachninae; Coccinellidae); its taxonomy, distribution and host plants in Pakistan. Sarhad J Agric 28(3):421-427

Niederwieser F (2017) Guidelines for the control of tomato leafminer (Tuta absoluta) on potato. CHIPS 31(1):30-32

Niño L (2004) Revisión sobre la polilla de la papa Tecia solanivora en Centro y Suramerica. Suplemento de la Revista Latinoamericana de la papa, pp 4-22

Noetzel DM, Cutkomp LK, Harein PK (1985) Estimated annual losses due to insects in Minnesota 1981-1983. University of Minnesota Agricultural Experiment Station Bulletin 2541

Notz AP (1992) Distribution of eggs and larvae of Scrobipalpula absoluta in potato plants. Rev Facul Agron (Maracay) 18:425-432

Oerke EC, Dehne HW, Schönbeck F, Weber A (1994) Crop production and crop protection. Estimated losses in major food and cash crops. Elsevier Science, Amsterdam, p 808

OIRSA (2015a) El psílido de la papa y tomate Bactericera (Paratrioza) cockerelli (Sulc) (Hemiptera: Triozidae): ciclo biológico; la relación con las enfermedades de las plantas y la estrategia del manejo integrado de plagas en la región del OIRSA. https://www.oirsa.org/ contenido/Manual\%20Bactericera\%20Cockerelli\%20version\%201.3.pdf

OIRSA (2015b) Manual de procedimientos para la vigilancia, prevención y control de la polilla del tomate Tuta absoluta (Lepidóptera: Gelechiidae) en la región del OIRSA. https://www. oirsa.org/contenido/2018/Sanidad_Vegetal/Manuales\%20OIRSA\%202015-2018/Manual\%20 T\%C3\%A9cnico\%20de\%20Tuta\%20absoluta\%20marzo\%2010,\%202017.pdf. Accessed 10 Oct 2017

OIRSA (2016) El psílido de la papa y tomate Bactericera (Paratrioza) cockerelli (Sulc) (Hemiptera: Triozidae): ciclo biológico; la relación con las enfermedades de las plantas y la estrategia del manejo integrado de plagas en la región del OIRSA. Editorial Tauro, Mexico. p. 48 
Orlandini S, Magarey RD, Woo Park E, Sporleder M, Kroschel J (2017) Methods of agroclimatology: modeling approaches for pests and diseases. In: Hatfield JL, MVK S, Prueger JH (eds) Agroclimatology. Linking agriculture to climate. Agron Monogr 60. ASA, CSSA, and SSSA, Madison, WI. https://doi.org/10.2134/agronmonogr60.2016.0027

Orozco FA, Cole DC, Forbes G, Kroschel J, Wanigaratne S, Arica D (2009) Monitoring adherence to the International Code of Conduct-highly hazardous pesticides in central Andean agriculture and farmers' rights to health. Int J Occup Environ Health 15(3):255-268

Ortiz O, Alcázar J, Catalán W, Cerna V (1996) Economic impact of IPM practices on the Andean potato weevil in Peru. In: Walker TS, Crissman CC (eds) Case studies of the economic impact of CIP related technologies. International Potato Center (CIP), Lima, Peru, pp 95-113

Pacheco DM (2015) Patogenicidad de dos nematodos entomopatógenos (Heterorhabditis sp y Steinernema sp) sobre larvas y pupas de Prodiplosis longifila en cultivos de tomate (Lycopersicum esculentum Miller). Dissertation, Universidad Nacional Pedro Ruiz Gallo

Parker WE, Howard JJ (2001) The biology and management of wireworms (Agriotes spp.) on potato with particular reference to the UK. Agric For Entomol 3(2):85-98

Pathania M, Chandel RS (2016) Life history strategy and behaviour of white grub, Brahmina coriacea (Hope) (Coleoptera: Scarabaeidae: Melolonthinae) an invasive pest of potato and apple agro-ecosystem in northwestern India. Oriental Insects 51(1):46-69

Pell JK, Eilenberg J, Hajek AE, Steinkraus DS (2001) Biology, ecology and pest management potential of entomophthorales. In: Butt TM, Jackson C, Magan N (eds) Fungi as biocontrol agents: progress, problems and potential. CAB International, Wallingford, UK, pp 71-154

Pollet A, Barragan A, Zeddam JL, Laery X (2003) Tecia solanivora, a serious biological invasion of potato cultures in South America. Int Pest Control 45(3):139-144

Powell W, Pell JK (2017) Biological control. In: Van Emden HF, Harrington R (eds) Aphids as crop pests, 2nd edn. CABI Publishing, Wallingford, pp 469-514

Pundt L (2007) Biological control of two-spotted spider mites. College of Agriculture, Health and Natural Resources, UConn Extension, The University of Connecticut, USA. http://ipm.uconn. edu/documents/raw2/html/664.php?display=print. Accessed 2 Nov 2018

Puttarudriah M, Krishnamurti B (1954) Problem of Epilachna control in Mysore: Insecticidal control found inadvisbale when natural incidence of parasites is high. Indian J Entomol 16:137-141

Quiroz R, David AR, Kroschel J, Andrade-Piedra J, Barreda C, Condori B, Mares V, Monneveux P, Perez W (2018) Impact of climate change on the potato crop and biodiversity in its center of origin. Open Agric 3:273-283. https://doi.org/10.1515/opag-2018-0029

Radcliffe EB, Johnson KB (1994) Biology and Management of Leafhoppers on Potato. In: Zehnder GW, Powelson ML, Jansson RK, Raman KV (eds) Advances in Potato Pest Biology and Management, APS Press, Saint Paul, MN, pp 71-82

Reátegui F, Wilson J, Ayquipa G, Neyra S (2009) Actividad entomopatógena de cuatro especies de hongos sobre (Diptera: Cecidomyiidae). REBIOL 29(1):1-6

Rehman M, Melgar J, Rivera C, Urbina N, Idris AM, Brown JK (2010) First report of Candidatus Liberibacter psyllaurous or Ca. Liberibacter solanacearum associated with severe foliar chlorosis, curling, and necrosis and tuber discoloration of potato plants in Honduras. Plant Dis 94:376

Salazar L (1995) Los virus de la papa y su control. Centro Internacional de la Papa (CIP), Lima, Peru

Sanchez G, Vergara C (2002) Plagas del cultivo de papa. Departamento de Entomologia y Fitopatologia, UNALM, Lima, Peru

Sarmiento J (1997) Manejo de Prodiplosis longifila Gagné. Perú, p 1-4

Schaub B, Kroschel J (2017) Developing a biocontrol strategy to protect stored potato tubers from infestation with potato tuber moth species. J Appl Entomol 142(1-2):78-88. https://doi. org/10.1111/jen. 12426

Schaub B, Carhuapoma P, Kroschel J (2016) Guatemalan potato tuber moth, Tecia solanivora (Povolny 1973). In: Kroschel J, Mujica N, Carhuapoma P, Sporleder M (eds) Pest distribution and risk atlas for Africa-potential global and regional distribution and abundance 
of agricultural and horticultural pests and associated biocontrol agents under current and future climates. International Potato Center (CIP), Lima, Peru, pp 24-38. https://doi. org/10.4160/9789290604761. (online publication: http://cipotato.org/riskatlasforafrica/)

SENASICA (2016) Palomilla del tomate Tuta absoluta Meyrick. Ficha Técnica 28:71

Song GH, Wu WW, Zhao QL (2008) Infection law and the control of 28-spot ladybird. Jilin Veg 1:50 Spencer KA (1973) Agromyzidae (Diptera) of Economic Importance. The Netherlands: Junk, The Hague

Spencer KA (1990) Host specialization in the world Agromyzidae Diptera. The Netherlands: Kluwer Academic Publisher

Sporleder M (2003) The granulovirus of the potato tuber moth Phthorimaea operculella Zeller characterisation and prospects for effective mass production and pest control (Dissertation). Tropical Agriculture 13, Advances in Crop Research 3. Margraf Publishers, Weikersheim, Germany, 196 pp.

Sporleder M, Kroschel J (2008) The potato tuber moth granulovirus (PoGV): use, limitations and possibilities for field applications. In: Kroschel J, Lacey L (eds) Integrated pest management of the potato tuber moth, Phthorimaea operculella Zeller-a potato pest of global. Tropical Agriculture 20, Advances in Crop Research importance 10. Margraf Publishers, Weikersheim, Germany, pp 49-71

Sporleder M, Lacey L (2013) Biopesticides. In: Giordanengo P, Vincent C, Alyokhin A (eds) Insect pests of potato: global perspectives on biology and management. Academic Press, Oxford, pp 463-497

Sporleder M, Kroschel J, Gutierrez Quispe MR, Lagnaoui A (2004) A temperature-based simulation model for the potato tuber worm, Phthorimaea operculella Zeller (Lepidoptera; Gelechiidae). Environl Entomol 33(3):477-486

Sporleder M, Tonnang HEZ, Carhuapoma P, Gonzales JC, Juarez H, Kroschel J (2013) Insect Life Cycle Modeling (ILCYM) software- a new tool for regional and global insect pest risk assessments under current and future climate change scenarios. CABI Book Publication, pp 412-427

Sporleder M (2003) The granulovirus of the potato tuber moth Phthorimaea operculella Zeller characterisation and prospects for effective mass production and pest control (Dissertation). Tropical Agriculture 13, Advances in Crop Research 3. Margraf Publishers, Weikersheim, Germany, 196 pp

Sporleder M, Carhuapoma P, Kroschel J (2016) Andean potato tuber moth, Symmetrischema tangolias (Gyen 1913). In: Kroschel J, Mujica N, Carhuapoma P, Sporleder M (eds) Pest distribution and risk atlas for Africa-potential global and regional distribution and abundance of agricultural and horticultural pests and associated biocontrol agents under current and future climates. International Potato Center (CIP), Lima, Peru, pp 39-53. https://doi. org/10.4160/9789290604761. (online publication: http://cipotato.org/riskatlasforafrica/)

Sporleder M, Schaub B, Aldana G, Kroschel J (2017) Temperature-dependent phenology and growth potential of the Andean potato tuber moth, Symmetrischema tangolias (Gyen) (Lep., Gelechiidae). J Appl Entomol 141:202-218. https://doi.org/10.1111/jen.12321

Steele C (2011) Wireworm Factsheet. Growers' advice. Potato Council. https://potatoes.ahdb. org.uk/sites/default/files/publication_upload/Growers\%20Advice\%20-\%20Wireworm\%20 Factsheet.pdf

Stenberg JA (2017) A conceptual framework for integrated pest management. Trends Plant Sci 22(9):759-769. https://doi.org/10.1016/j.tplants.2017.06.010

Strand L (2006) Integrated pest management for potatoes in the western United States, vol 3316. UCANR Publications

Tolman JH, McLeod DGR, Harris CR (1986) Yield losses in potatoes, onions and rutabagas in Southwestern Ontario, Canada - the case for pest control. Crop Prot 5 (4):227-237

Venkatesha MG (2006) Seasonal occurrence of Henosepilachna vigintioctopunctata (F.) (Coleoptera: Coccinellidae) and its parasitoid on ashwagandha in India. J Asia-Pacific Entomol 9(3):265-268

Vereijssen J, Smith GR, Weintraub PG (2018) Bactericera cockerelli (Hemiptera: Triozidae) and Candidatus Liberibacter solanacearum in Potatoes in New Zealand: Biology, Transmission, 
and Implications for Management. J Integr Pest Manag 9(1):13. https://doi.org/10.1093/jipm/ pmy007

Verma KD, Chandla VK, Trivedi TP (1994) Present status and management of potato pests in India. Annals of Entomology 12(2):73-79

Vincent C, Alyokhin A, Giordanengo P (2013) Potatoes and their pests-setting the stage. In: Giordanengo P, Vincent C, Alyokhin A (eds) Insect pests of potato: global perspectives on biology and management. Academic Press, Oxford, pp 3-8

Vishwakarma R, Prasad PH, Ghatak SS, Mondal S (2011) Bio-efficacy of plant extracts and entomopathogenic fungi against epilachna beetle, Henosepilachna vigintioctopunctata (Fabricius) infesting bottle gourd. J Insect Sci 24(1):65-70

Visser D (2012) Beetles and their grubs that damage potato tubers. Technical news. ARCRoodeplaat. http://www.potatoes.co.za/SiteResources/documents/Beetles\%20and\%20 their\%20grubs\%20that\%20damaged\%20potato\%20tubers\%202012.pdf

Visser D, Stals R (2012) Temnorhynchus coronatus (Fabricius) (Scarabaeidae: Dynastinae), potentially a pest of sweet potato in South Africa. Afr Entomol 20(2):402-407

Weintraub PG (2001) Effects of cyromazine and abamectin on the pea leafminer Liriomyza huidobrensis (Diptera: Agromyzidae) and its parasitoid Diglyphus isaea (Hymenoptera: Eulophidae) in potatoes. Crop Prot 20:207-213

Weintraub PG, Scheffer SJ, Visser D, Valladares G, Soares Correa A, Shepard BM, Rauf A, Murphy ST, Mujica N, MacVean C, Kroschel J, Kishinevsky M, Joshi RC, Johansen NS, Hallett RH, Civelek HS, Chen B, Blanco Metzler H (2017) The invasive Liriomyza huidobrensis (Diptera: Agromyzidae): understanding its pest status and management globally. J Insect Sci 17(1):1-27. https://doi.org/10.1093/jisesa/iew121

Workneh F, Henne DC, Childers AC, Paetzold L, Rush CM (2012) Assessments of the Edge Effect in Intensity of Potato Zebra Chip Disease. Plant Dis 96 (7):943-947

Xu R, Zhou J, Chen Z, Jia Y, Xu K (2013) Phototactic Behavior of Henosepilachna vigintioctomaculata Motschulsky (Coleoptera: Coccinellidae). The Coleopterists Bulletin 69(4):806-812

Yao XL, Li CQ, Gao ZL, Lu HM, Lan L, Liu H (1992) Preliminary observations on biology of potato ladybird. J Shaanxi Agric Sci 5(1):28-29

Zhou J, Xu R, Chen Z, Jia Y, Xu K (2015) Phototactic behavior of Henosepilachna vigintioctomaculata Motschulsky (Coleoptera: Coccinellidae). Coleopt Bull 69(4):806-812

Zuckerman L (1999) The potato: how the humble spud rescued the western world. North Point Press, New York

Open Access This chapter is licensed under the terms of the Creative Commons Attribution 4.0 International License (http://creativecommons.org/licenses/by/4.0/), which permits use, sharing, adaptation, distribution and reproduction in any medium or format, as long as you give appropriate credit to the original author(s) and the source, provide a link to the Creative Commons license and indicate if changes were made.

The images or other third party material in this chapter are included in the chapter's Creative Commons license, unless indicated otherwise in a credit line to the material. If material is not included in the chapter's Creative Commons license and your intended use is not permitted by statutory regulation or exceeds the permitted use, you will need to obtain permission directly from the copyright holder.

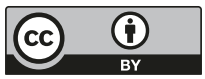

